\title{
Large mammals (carnivores, artiodactyls) from Solna Jama Cave (Bystrzyckie Mts, Southwestern Poland) in the context of faunal changes in the postglacial period of Central Europe
}

\author{
Adrian Marciszak, Wiktoria Gornig, and Krzysztof Stefaniak
}

\begin{abstract}
Mammals from Solna Jama Cave were parts of two main faunal assemblages. The earlier one, dated as MIS 3, included few bones of the Ursus ingressus and a single $\mathrm{m} 2$ of the huge Ursus arctos priscus. The later one, of postglacial age (MIS 1), was represented, among others, by the Canis lupus, Mustela eversmanii and Felis silvestris. The most impressive find, a skull and partial skeleton of a very large and robust Gulo gulo, is the only reliable Polish record of the species from postglacial period. The find expands the knowledge of the Sudetes fauna from the Pleistocene/Holocene boundary. Morphometric characteristics of carnivores, which greatly outnumbered the other mammal taxa in the site, showed some adaptation to cool climatic conditions.
\end{abstract}

Adrian Marciszak. Department of Paleozoology, Institute of Environmental Biology, Faculty of Biological Sciences, University of Wrocław, Sienkiewicza 21, 50-335 Wrocław, Poland. adrian.marciszak@uwr.edu.pl Wiktoria Gornig. Department of Paleozoology, Institute of Environmental Biology, Faculty of Biological Sciences, University of Wrocław, Sienkiewicza 21, 50-335 Wrocław, Poland._wiktoria.gornig@uwr.edu.pl Krzysztof Stefaniak. Department of Paleozoology, Institute of Environmental Biology, Faculty of Biological Sciences, University of Wrocław, Sienkiewicza 21, 50-335 Wrocław, Poland.

krzysztof.stefaniak@uwr.edu.pl

Keywords: postglacial; Gulo gulo; calvarium; adaptation; Bergmann's rule; fossil cave fauna

Submission: 22 June 2015 Acceptance: 30 January 2017

\section{INTRODUCTION}

Solna Jama Cave (50011'22" N, 16034'47" E, ca. 600 a.s.l., and ca. $10 \mathrm{~m}$ above the valley bottom) is also known as Gniewoszowska Cave, Salt Pit or Salzlöcher Höhle. Its name is most probably derived from the white, coarse, salt-resembling, crystalline limestones which form the lens. The site is situated in an abandoned quarry near Gniewo- szów village (Bystrzyckie Mts) (Figure 1) and is one of the longest known caves in the Sudety Mts. It is located in one of the small outcrops of crystalline limestone (geological structures common in the region of Międzylesie) between a small stream bed and a karst spring. The origin of the locality is probably associated with water flow from one of the neighbouring streams through the fissured crystal-

Marciszak, Adrian, Gornig, Wiktoria, and Stefaniak, Krzysztof. 2017. Large mammals (carnivores, artiodactyls) from Solna Jama Cave (Bystrzyckie Mts, Southwestern Poland) in the context of faunal changes in the postglacial period of Central Europe. Palaeontologia Electronica 20.1.3A: 1-37

palaeo-electronica.org/content/2017/1740-mammals-from-solna-jama-cave

Copyright: February 2017 Palaeontological Association 


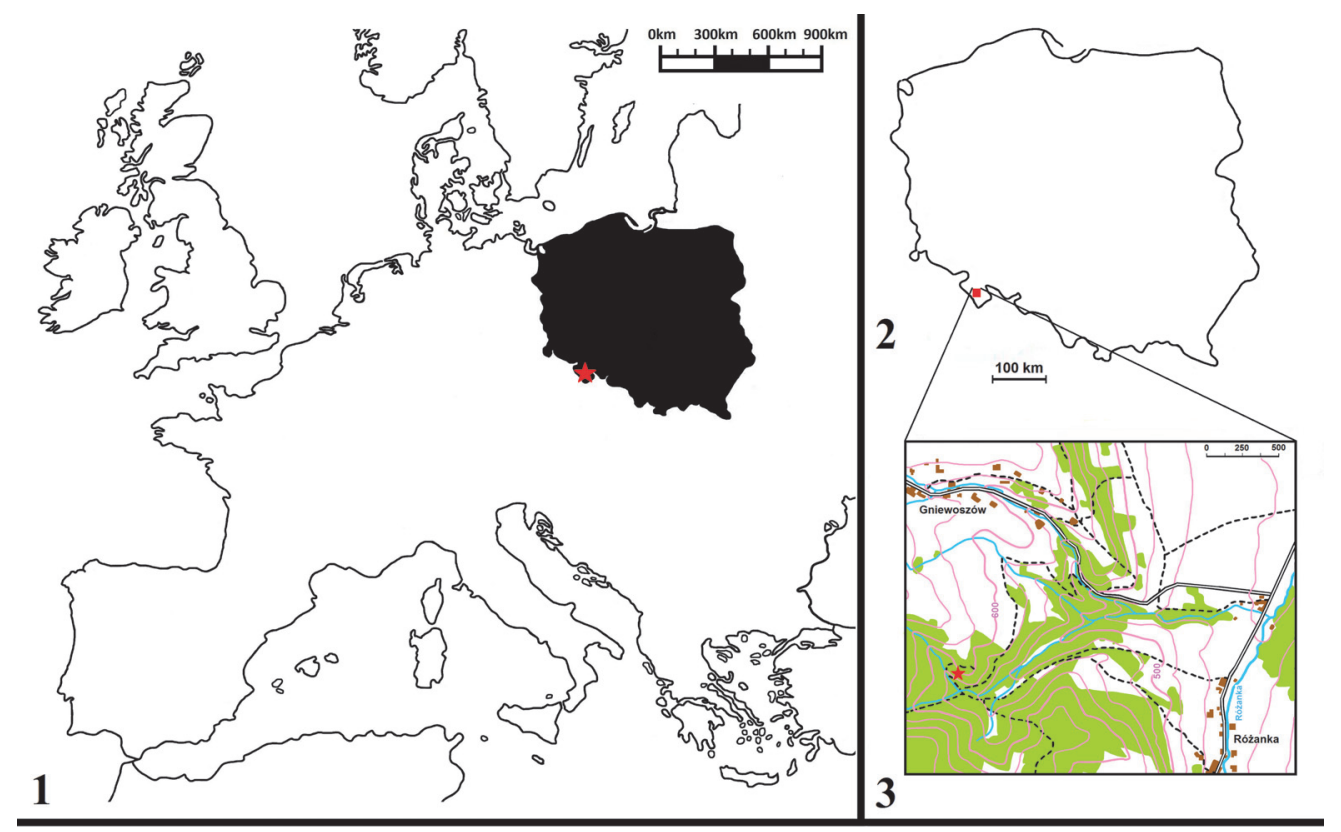

4

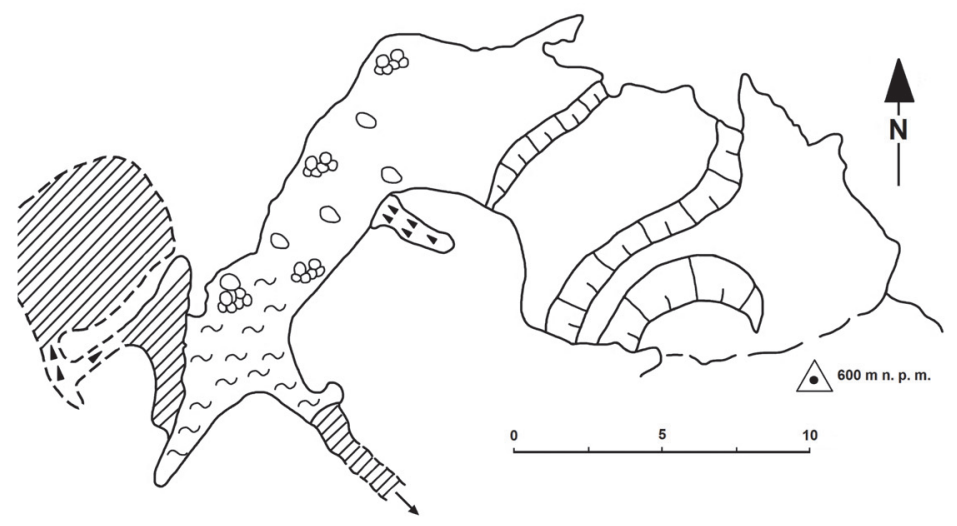

FIGURE 1. Location of Solna Jama Cave in Europe indicated by red star (1), in Poland marked by red square (2), in the environs of Gniewoszów village indicated by red star (3) and map of the site (4) after Pulina (1996) and Stefaniak et al. (2009).

line limestones (Figure 2). The cave is ca. $50 \mathrm{~m}$ long, has one entrance, one big, oval chamber with a few adjoining shallow niches and corridors; small karst springs drained through the cave. In 1985, when the largest chamber of the cave was discovered, its floor was flooded. The cave must have still had a natural entrance from the surface during the Holocene. Above the cave fissure, a karstic breccia with the cave bear remains was discovered, indicating that the cave must have had a higher situated horizon, so far undiscovered. Before World War II the cave was considerably enlarged as a result of removal of most of its sediments in 19351936 (Kowalski, 1954). The detailed description presented by Dittrich $(1935,1939)$ differs considerably from the present-day situation. The cave lacks its beautiful and rich sinter mantle, now almost completely destroyed.

Solna Jama Cave was known since half of the 18th century and was first mentioned by Zimmermann (1789) and later by Scholz (1843). Before the palaeontological exploration, it was mostly known for its interesting extant fauna. In 1921, Arndt mentioned the presence of a crustacean in the cave's pool (Arndt, 1921, 1923). Later, it was recognised by Schellenberg (1935) as Niphargus tatrensis Wrześniowski, 1888. Recent Rhizopoda (16 forms identified) were studied by Pateff (1926), aquatic invertebrates by Schellenberg (1932, 1935) and Chiroptera by Seidel (1927). Besides, the extant fauna was more or less thoroughly described by Pax (1921), Otto (1923) and Frenzel (1937). Additionally, Stammer (1936) focused on 


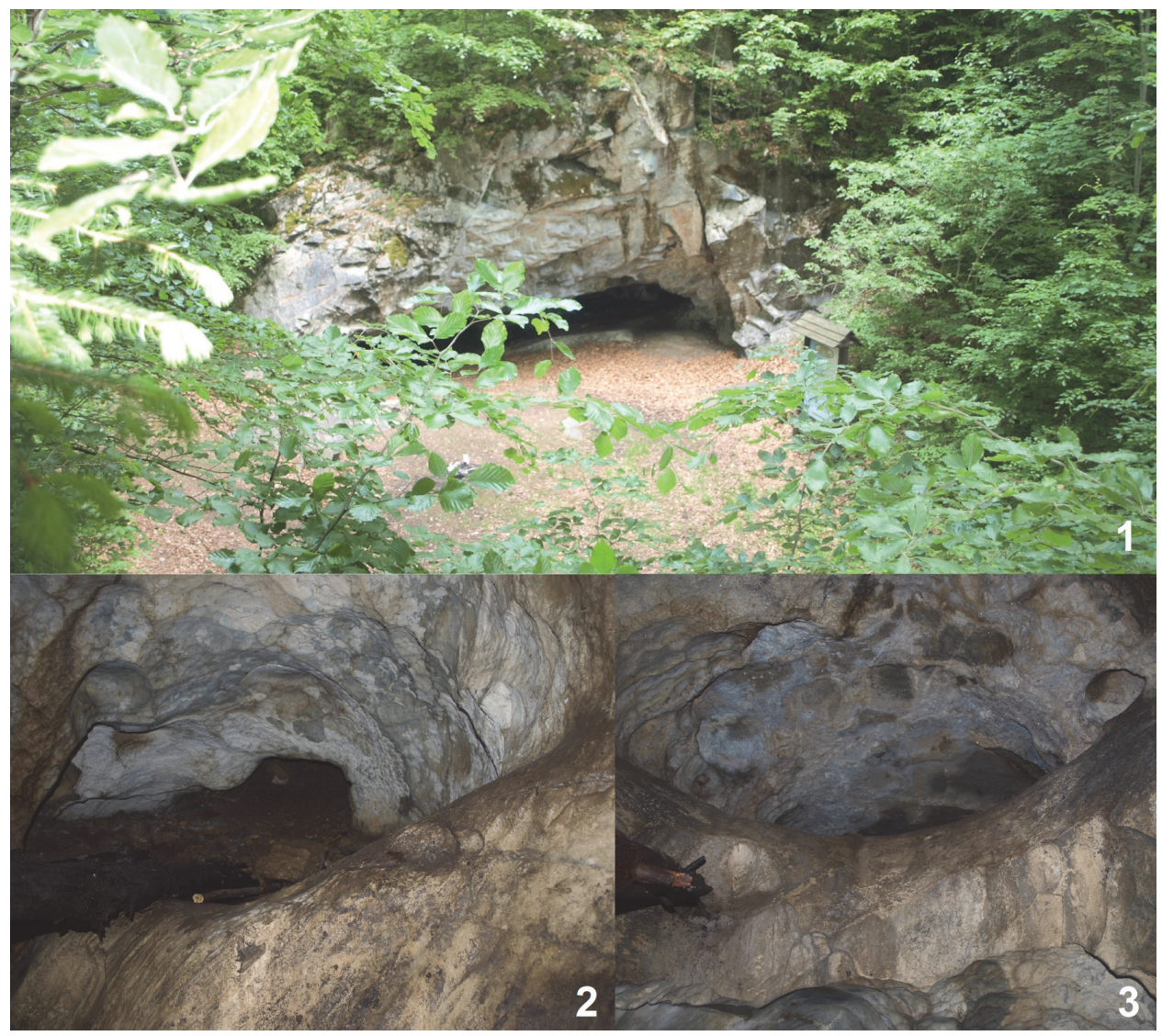

FIGURE 2. Environs of Solna Jama Cave entrance (1), showing the fissured crystalline limestones, in which the cave developed. The "Wolverine Niche" (2) and the corrosion, phreatic features of the cave passage (3). The "Wolverine Niche" is the place in the cave, where partially preserved skeleton of particularly large Gulo gulo was found (Photo by K. Stefaniak).

the aquatic invertebrate fauna; he found seven species of Nematoda, three species of Oligochaeta, three species of Tardigrades and four species of Crustacea. The faunistic studies continued also after World War II, for example Stach studied Collembola (Stach, 1939, 1945, 1947, 1949a, 1949b), but were less extensive (Kowalski, 1954). The invertebrate fauna was inventoried by Skalski (1984, 1994), Pomorski (1990, 1992), Skarżyński (2001) and Dumnicka (2007). Three wintering bat species were recorded in the cave: Myotis myotis (Borkhausen, 1797), M. daubentoni (Kuhl, 1819) and Plecotus auritus (Linnaeus, 1758) (Wołoszyn, 1968, 1971; Furmankiewicz and Furmankiewicz, 2002). Finally, all the information on Solna Jama Cave was summarised by Stefaniak and Bieroński (2009) and Stefaniak et al. (2009).

Despite the early discovery of the cave, its paleontological exploration started as late as the 1980s and was carried out by Teresa Wiszniowska's team and co-workers. A small niche, ending with a narrow crevice, was found at the end of the cave. This chamber - the largest known so far was situated beyond the so-called "lake" and named "Wolverine Niche". It was filled by sediments (mostly cave loams, with Holocene humus on top) together with loose bone breccia. It is also the place where Gulo gulo skeleton together with the postglacial faunal assemblage was found (Figure 2).

The faunal list includes: Sorex minutus Linnaeus, 1766; Crocidura sp.; Myotis myotis; Plecotus auritus; Sciurus vulgaris Linnaeus, 1758; Myodes glareolus (Schreber, 1780); Arvicola terrestris (Linnaeus, 1758); Cricetus cricetus (Linnaeus, 1758); Microtus sp.; Canis lupus Linnaeus, 1758; Vulpes vulpes (Linnaeus, 1758); Ursus ingressus Rabeder et al., 2004; Ursus arctos priscus Goldfuss, 1818; Gulo gulo (Linnaeus, 1758); Meles meles (Linnaeus, 1758); Martes martes (Linnaeus, 1758); Mustela eversmanii Lesson, 1827; Mustela nivalis Linnaeus, 1766; Felis silvestris Schreber, 1777; Capreolus capreolus Lin- 
naeus, 1758; and Bison/Bos sp. (Stefaniak and Bieroński, 2009; Stefaniak et al., 2009).

\section{MATERIAL AND METHODS}

Measurements were taken point to point, with an electric calliper, to the nearest $0.01 \mathrm{~mm}$. Each value given here is the mean of three measurements. Additionally, some measurements were taken using a set for image analysis Olympus (Olympus stereo microscope ZSX 12, the camera Olympus DP 71, the program Cell D). This set, together with camera Canon EOS 5D, was also used to prepare the photographic documentation of the fossil material. Statistical analysis was performed using "Statistica" (version 10.0) software. The number of bones assigned to the taxon was specified as NISP (number of identified specimens), while the minimum number of individuals assigned to the particular taxon as specified as MNI. The number of individuals assigned to the species is based on the morphological and metrical values, stage of preservation, the colour of the bone etc. Osteological and dental terminology follow von den Driesch (1976) and Döppes (2001). The measurements scheme of the skull (cranium and mandible) is shown in Appendices 1-7. These schemas are summarised using methods proposed by authors like Rabeder (1999) for ursids, Döppes (2001) or Marciszak (2012) for mustelids, or Schmid (1940) for felids. The measurements of the postcranial material follow von den Driesch (1976) and Hilpert (2006). Ursid morphotypes analysis was made based on methodology proposed by Rabeder (1999). All the examined material is stored at the Department of Paleozoology, University of Wrocław, numbers within collection ZPal/ JSJ/.

\section{SYSTEMATIC PALAEONTOLOGY}

Order CARNIVORA Bowditch, 1821

Family CANIDAE Fischer von Waldheim, 1817

Genus CANIS Linnaeus, 1758

Canis lupus Linnaeus, 1758

Specimens. Right complete metatarsale III (JSJ/ $\mathrm{Cl} / 1)$; left metatarsale $\mathrm{V}(\mathrm{JSJ} / \mathrm{Cl} / 2)$; complete ph III (JSJ/Cl/3).

Measurements. Metatarsal III (JSJ/Cl/1): L, 99.89 $\mathrm{mm}$; pL, $18.46 \mathrm{~mm}$; $\mathrm{pB}, 13.49 \mathrm{~mm}$; $\mathrm{mL}, 7.61 \mathrm{~mm}$; $\mathrm{mB}, 10.58 \mathrm{~mm}$; dL, $13.89 \mathrm{~mm}$; dB, $13.19 \mathrm{~mm}$. Mtts $\mathrm{V}(\mathrm{JSJ} / \mathrm{Cl} / 2): \mathrm{pL}, 13.92 \mathrm{~mm} ; \mathrm{pB}, 18.29 \mathrm{~mm} ; \mathrm{mL}$, $10.81 \mathrm{~mm} ; \mathrm{mB}, 8.29 \mathrm{~mm}$.

Remarks. The three postcranial bones $(\mathrm{NISP}=3)$ belonged to a large and robust individual $(\mathrm{MNI}=1)$, of general size and proportions comparable to those of big modern C. lupus. Although the individual was not small, much larger and massive specimens are known from other sites, also in the Sudetes, for example like Niedźwiedzia Cave. Unfortunately, no tooth remains, which would permit distinction between the different forms of $C$. lupus were found, and the few skeletal remains are insufficiently diagnostic. For this reason the large canid was classified simply as $C$. lupus.

The late Pleistocene Canis lupus is sometimes regarded as an ecomorph/chronosubspecies C. lupus spelaeus (Goldfuss, 1823). After its first description, this form was sometimes mentioned from different European sites, but usually only briefly, and almost never described in detail. The form/subspecies category tends to be employed rather freely in canid palaeontology. No statistically morphologically reliable features were given, which would allow to distinguish it as a separate form. Preliminary analysis of abundant, well-preserved material from Polish and Czech sites, however, indicates that the form differed somewhat in its morphology from the Holocene and modern specimens. Apart from the larger average size, it was also characterised by broader teeth and more robust postcranial bones. These differences require a more detailed analysis and are now under study.

Genus VULPES Frisch, 1775

Vulpes vulpes (Linnaeus, 1758)

Specimens. Nine bones: body of the left mandible with p4-m2 (JSJ/Vv/1); phalanx II (JSJ/Vv/2); left, damaged humerus (JSJ/Vv/3); damaged lumbar (JSJ/Vv/4); damaged lumbar (JSJ/Vv/5); damaged cervical (JSJ/Vv/6); damaged thoracic (JSJ/Vv/7); right c1 (JSJ/Vv/8); phalanx III (JSJ/Vv/9).

Measurements. Mandible (JSJ/Vv/1): 5, 70.87 $\mathrm{mm} ; 6,62.84 \mathrm{~mm} ; 7,58.74 \mathrm{~mm} ; 8,33.54 \mathrm{~mm}$; 9 , $29.36 \mathrm{~mm} ; 10,12.23 \mathrm{~mm} ; 11,29.73 \mathrm{~mm} ; 12,9.92$ $\mathrm{mm} ; 18,11.84 \mathrm{~mm} ; 19,6.49 \mathrm{~mm} ; 21,6.97 \mathrm{~mm}$; clL, $8.06 \mathrm{~mm}$; c1-B, $9.81 \mathrm{~mm}$; p3-L, $9.81 \mathrm{~mm}$; p3-B, $3.69 \mathrm{~mm}$; p4-L, $10.24 \mathrm{~mm}$; p4-B, $4.04 \mathrm{~mm}$; m1-L, $16.24 \mathrm{~mm}$; m1-L-tri, $10.37 \mathrm{~mm}$; m1-L-tal, $5.78 \mathrm{~mm}$; m1-B-tri, $6.83 \mathrm{~mm}$; m1-B-tal, $6.51 \mathrm{~mm}$. Humerus (JSJ/Vv/3): L, $131.97 \mathrm{~mm}$; pL, $27.64 \mathrm{~mm}$; pB, $22.97 \mathrm{~mm}$; mL, $9.65 \mathrm{~mm} ; \mathrm{mB}, 8.45 \mathrm{~mm}$; dL, 16.56 $\mathrm{mm}$; dB, $22.43 \mathrm{~mm}$; B-tro, $18.26 \mathrm{~mm}$. See Appendix 1 for measured parts.

Description. The nine bones are clearly of canid form, indistinguishable from $V$. vulpes and large in size. The state of preservation and colour indicate their subfossil character, possibly even younger than the other postglacial faunal elements. All were 
assigned to one, quite large specimen (NISP $=9$, $\mathrm{MNI}=1$ ).

Remarks. The species was recorded from many Pleistocene and Holocene sites in Poland, and also now it penetrates caves and rock shelters to raise cubs and store food. Like Meles meles, V. vulpes is regarded as a typical cave dweller which, due to digging burrows, may disturb the sediment structure (Sommer and Benecke, 2005).

Family URSIDAE Fischer von Waldheim, 1817 Genus URSUS Linnaeus, 1758

Ursus ingressus Rabeder, Hofreiter, Nagel, and Withalm, 2004

Specimens. Left, damaged fibula (JSJ/Ui/1) and left damaged pisiform (JSJ/Ui/2).

Description. The form was represented by only two postcranial bones, which failed to yield useful metric and morphological data. The pisiform is large and massive, the distal epiphysis in medial view is transversely much more pronounced than in Ursus arctos. The elongated and rounded palmar surface is more pronounced and larger, while the lateral and medial surfaces are longer and more convex. Fibulae of $U$. spelaeus and $U$. arctos are difficult to distinguish morphometrically and morphologically. According to Petronio et al. (2003), the morphology of the two forms shows no substantial differences and some minor differences like relatively more massive build in $U$. spelaeus generally overlap.

Remarks. Genetic studies of Ursus spelaeus sensu lato material from the Sudety Mts showed only the presence of $U$. ingressus (Baca et al., 2014). The material from Solna Jama Cave also represents this species, which was confirmed by analysis of ancient DNA. That means that $U$. ingressus was the only speleoid bear known till now, which inhabited the area of Sudeten Mountains during the late Pleistocene (Baca et al., 2014).

\section{Ursus arctos priscus Goldfuss, 1818} Figure 3

Specimens. Crown of the right $\mathrm{m} 2$ (JSJ/Us/1). Measurements. 1, $32.78 \mathrm{~mm}, 2,17.51 \mathrm{~mm}$; , $20.94 \mathrm{~mm}$; 4, $15.02 \mathrm{~mm}$; 5, $12.09 \mathrm{~mm}$; 6, 20.01 $\mathrm{mm} ;$ 7, $20.86 \mathrm{~mm}$. See Appendix 2 for measured parts.

Description. The single $\mathrm{m} 2$ of exceptionally large size is the only remains of Ursus arctos from Solna Jama (Figure 3). Its general outline is typically arctoid, with the posterior part of the crown only slightly broader than the anterior one. In the cave bear the posterior tooth part is much broader and wider on the buccal than in the examined individual. The anterior and posterior margins are rounded, the lingual edge is almost straight, while the buccal side of the crown is curved in its posterior part. In occlusal view, the tooth appears solid and bulky. The surface morphology is complicated, but much less so than in U. spelaeus. The metalophid complex is complicated, and represents morphotype D. The large, rounded and high protoconid is connected with the metaconid by an almost straight, thick ridge. Between the two main cusps, also two smaller, accessory cusplets are present: a smaller, rounded entprotoconid and a flat, elongated entmetaconid. The frontal ridge is packed with about a dozen cusplets of different sizes, connected and closely associated with each other, oval-shaped and rather low. The trigonid surface between this ridge and the metalophid complex is complicated by a few ribs and grooves, and the overall surface is quite deeply concave. The metastylid is longer but lower, with simple structure, with three metastylids. The median one is the largest and the highest, while the other two are lower and elongated. This structure lacks any other accessory cusplets, such as entoconid, metaconid or mesostylid, which are characteristic of stratigraphically older forms. The mesolophid represents primitive morphotype $B$, with a simple mesolophid, developed into a semicircular, thick ridge. The enthypoconid complex has a complicated structure (morphotype C/D), with a well-developed, large hypostylid. This cusp is accompanied by a few thick, long ridges. The hypoconulid is present, with a somewhat "cusplet"-like structure situated close to it. Its general shape and morphology indicate an arctoid bear, even if the measurements of this single tooth correspond to the respective large-sized teeth of the $U$. spelaeus. This was already observed by Sabol (1999, p. 88): "Sometimes the teeth of the subspecies $U$. arctos priscus have morphological signs, which are common in the species U. spelaeus too."

Remarks. Since the beginning of systematic cave research in the early nineteenth century, bear remains were found in vast numbers. The Ursus spelaeus had been known for a long time from different paleontological sites across Europe, when a distinct kind of bear was discovered. The second bear was usually smaller, with a rather flat forehead and arctoid-like morphological features. It was described by Goldfuss (1818a) under two different names. Thus from the very beginning the issue of $U$. arctos taxonomy was controversial. After recent re-examination, finally the name $U$. 


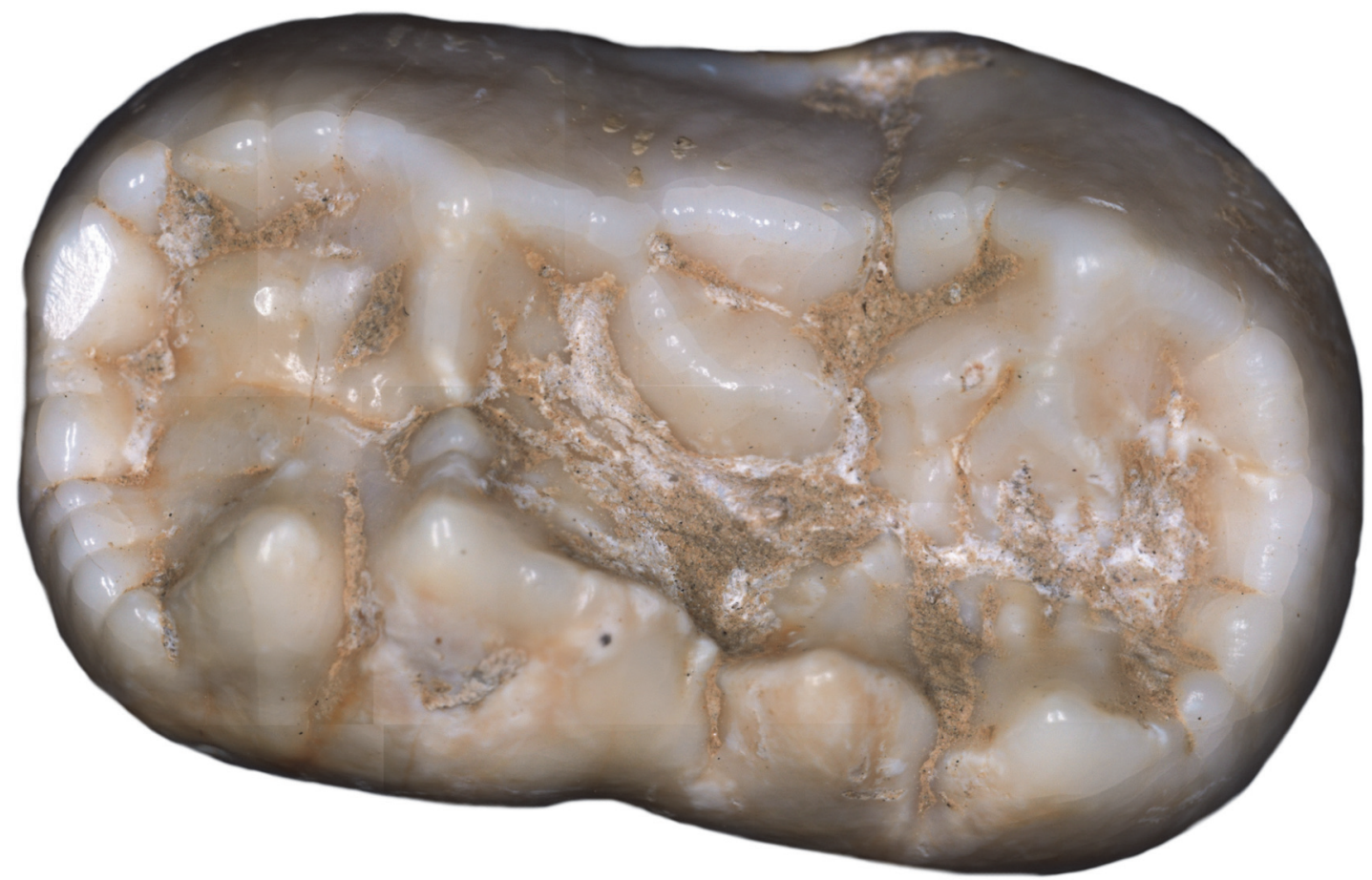

$10 \mathrm{~mm}$

FIGURE 3. Ursus arctos priscus m2 (JSJ/Ua/1) from Solna Jama Cave in occlusal view. Note robust build and arctoid shape of tooth, with only slightly expanded, buccal margin of the talonid. Scale bar equals $10 \mathrm{~mm}$.

arctos priscus Goldfuss, 1818 was established as senior, firstly used to designate a new form (Pacher, 2007).

The two main problems faced by scientists dealing with Ursus arctos taxonomy are the lack of well-specified morphometric characters and the absence of morphological features, which would allow to distinguish different forms/subspecies. As observed by Kurtén (1959, p. 81): "The bears in particular have been almost fantastically misinterpreted by incompetent taxonomists." A single species, U. arctos, was split into more than 150 socalled species, forms, subspecies and even several genera. Some large, late Pleistocene individuals are so different from the modern, European specimens that sometimes in the past really bizarre hypotheses were created. Based on their flat crania (missing glabella), dentition morphology and the supposed late Pleistocene age, it was concluded that they must have belonged to a hybrid between $U$. spelaeus and $U$. arctos or, less likely, to a not yet fully grown $U$. spelaeus (Ehrenberg, 1929).
Fossil and subfossil specimens from Central European archaeological and paleontological localities can be divided into two main groups and classified based on their morphometric and morphological characters. The first group represents the huge, primitive $U$. arctos priscus, dated as the late middle and late Pleistocene. Most of them are dated as younger than $100 \mathrm{Ka}$ (somewhere between 70 and $20 \mathrm{Ka}$ ), but bears from a few localities like Biśnik or Południowa Caves are almost certainly older. The second group includes individuals whose smaller and slighter build places them in the nominate subspecies $U$. arctos arctos, recently occurring in Central Europe. Almost all of them are younger than $15 \mathrm{Ka}$, but single individuals may be slightly older.

According to Wojtal et al. (2015), the Polish cave sites indicate that Ursus arctos may have replaced $U$. ingressus in the second half of the last glacial, but this scenario is not obvious and needs further verification. The oldest $\mathrm{C} 14$ date for $U$. arctos in Poland, Kraków Spadzista: $24360 \pm 160$ cal. $\mathrm{BP}$, is almost within the range of the youngest 
dates obtained so far for $U$. ingressus from Poland: Komarowa (24550 \pm 220 cal.BP) and Deszczowa (24580 \pm 200 cal.BP) caves (Wojtal et al., 2015). A much older $(36500 \pm 800$ cal. BP $)$ date was obtained from an incisor from layer $2 \mathrm{~g}$ of Mamutowa Cave. All these dates suggest the occurrence of $U$. arctos also in cold phases of the last glacial, but they do not resolve the main problem of the cooccurrence of both bears. Some radiocarbon dates from open and cave localities are relatively young, and are certainly beyond the extinction dates of $U$. ingressus (Wiśniewski et al., 2009).

Another important issue is the large size of the examined $\mathrm{m} 2$ from Solna Jama, and of some populations of late middle and late Pleistocene $U$. arctos in general (e.g., Mostecký, 1963; Musil, 1964; Ballesio, 1983; Musil, 1996; Sabol, 2001a, 2001b; Rabeder et al., 2009). The size may have been associated only with the influence of temperature; according to the Bergman rule larger individuals are found in harsher climate. However, the matter is more complicated, due to the fact that large forms are also known from interglacial/interstadial periods. It seems likely that the large size was also associated with a high-protein diet, which the huge bears derived from two sources: hunting and kleptoparasitism. They could roam vast open areas in search of prey and food, also taking advantage of seasonal abundance of fish, berries etc. Their size was of considerable advantage during confrontation with other predators, and the abundance of large herds of hoofed mammals could provide the necessary amount of food to survive for such a large predator. The retreat of the glacier was followed by rebuilding of the fauna; the open grasslands were replaced by thick forests, with numerous but scattered small and medium-sized species. The world around the huge, hypercarnivorous $U$. arctos changed, and now it offered much more favourable conditions for smaller and more versatile animals. The huge, primitive, carnivorous $U$. arctos priscus was replaced by a smaller, more omnivorous $U$. arctos arctos, which then survived to this day. It is not clear if it was competition that was concerned, or filling the free niche by one form, following the decline of another. Preliminary results of isotopic studies (Krajcarz et al., 2014c) also confirm a higher proportion of meat in the diet of the Pleistocene forms. In conclusion, we agree with many earlier authors (e.g., Thenius, 1956; Mostecký, 1963; Musil, 1964; Musil, 1996; Sabol, 2001a, 2001b; Pacher, 2007) on that the true $U$. arctos priscus may have represented quite a differ- ent form, that was adapted to open, steppe-like habitats.

Family MUSTELIDAE Fischer von Waldheim, 1817 Genus GULO Pallas, 1780

Gulo gulo (Linnaeus, 1758)

Figures 4-6, Appendix 8

Specimens. Seventy six bones belong to one individual: cranium without left zygomatic arch and posterior part of neurocranium and with left I1-M1 (P4 worn) and right I1-C1 and P2-M1 (JSJ/Gg/1-1); small piece ofv the left mandible with $\mathrm{p} 1, \mathrm{p} 3$ and $\mathrm{m} 1$ (JSJ/Gg/1-2); right mandible with i3 and p2-m2 (now p4-m2 are strongly worn) and ramus fragment (JSJ/Gg/1-3); damaged, left scapula (JSJ/ $\mathrm{Gg} / 1-4)$; damaged shaft of left humerus with fragment of proximal epiphysis (JSJ/Gg/1-5); right radius (JSJ/Gg/1-6); shaft fragment of the right tibia with a piece of proximal epiphysis (JSJ/Gg/17); right fibula (JSJ/Gg/1-8); damaged, left coxae (JSJ/Gg/1-9); damaged cervical (JSJ/Gg/1-10); 3 caudals (JSJ/Gg/1-11-13); 3 costaes without distal epiphysis (JSJ/Gg/1-14-16); damaged baculum (JSJ/Gg/1-17); right calcaneus (JSJ/Gg/1-18); right talus (JSJ/Gg/1-19); left pisiform (JSJ/Gg/1-20); right pisiform (JSJ/Gg/1-21); left navicular (JSJ/Gg/ 1-22); left cuboid (JSJ/Gg/1-23); left cuneiform I (JSJ/Gg/1-24); right cuneiform II (JSJ/Gg/1-25); right cuneiform III (JSJ/Gg/1-26); left metacarpal I (JSJ/Gg/1-27); left metacarpal II (JSJ/Gg/1-28); right metacarpal III (JSJ/Gg/1-29); left metacarpal IV without distal epiphysis (JSJ/Gg/1-30); left metacarpal $V$ (JSJ/Gg/1-31); left metatarsal I without proximal epiphysis (JSJ/Gg/1-32); left metatarsal II (JSJ/Gg/1-33); left metatarsal III (JSJ/Gg/1-34); left metatarsal IV (JSJ/Gg/1-35); right metatarsal V (JSJ/Gg/1-36); 14 phalanges I (JSJ/Gg/1-37-50); 10 phalanges II (JSJ/Gg/1-51-60); 9 phalanges III (JSJ/Gg/1-61-69); 7 sesamoides (JSJ/Gg/1-7076).

Measurements. Cranium (JSJ/Gg/1): 1, (185.00) $\mathrm{mm}$; 4, $84.70 \mathrm{~mm}$; 6, $91.56 \mathrm{~mm} ; 7,55.26 \mathrm{~mm}$; 8, $75.24 \mathrm{~mm} ; 9,94.65 \mathrm{~mm} ; 10,65.47 \mathrm{~mm} ; 11,50.37$ $\mathrm{mm} ; 12,(122.00) \mathrm{mm} ; 13,30.16 \mathrm{~mm} ; 14,52.96$ $\mathrm{mm} ; 15,84.60 \mathrm{~mm} ; 16,66.43 \mathrm{~mm} ; 17,21.3 \mathrm{~mm}$; $18,56.28 \mathrm{~mm} ; 19,47.46 \mathrm{~mm} ; 20,57.75 \mathrm{~mm} ; 21$, $42.04 \mathrm{~mm} ; 25,30.83 \mathrm{~mm} ; 26,25.98 \mathrm{~mm} ; 31,62.15$ $\mathrm{mm} ; 32,65.70 \mathrm{~mm}$; I1-L, $8.09 \mathrm{~mm}$ (right), $8.40 \mathrm{~mm}$ (left); I1-B, $4.53 \mathrm{~mm}$ (right), $4.34 \mathrm{~mm}$ (left); I2-L, $8.79 \mathrm{~mm}$ (right), $8.86 \mathrm{~mm}$ (left); I2-B, $4.86 \mathrm{~mm}$ (right), $4.41 \mathrm{~mm}$ (left); I3-L, $10.87 \mathrm{~mm}$ (right), 10.51 mm (left); I3-B, $7.97 \mathrm{~mm}$ (right), $7.82 \mathrm{~mm}$ (left); C1L, $14.48 \mathrm{~mm}$ (right), $14.57 \mathrm{~mm}$ (left); C1-B, 11.31 $\mathrm{mm}$ (right), $11.46 \mathrm{~mm}$ (left); P1-L, $5.13 \mathrm{~mm}$ (left); P1-B, 4.56 mm (left); P2-L, 9.16 mm (right), 9.21 

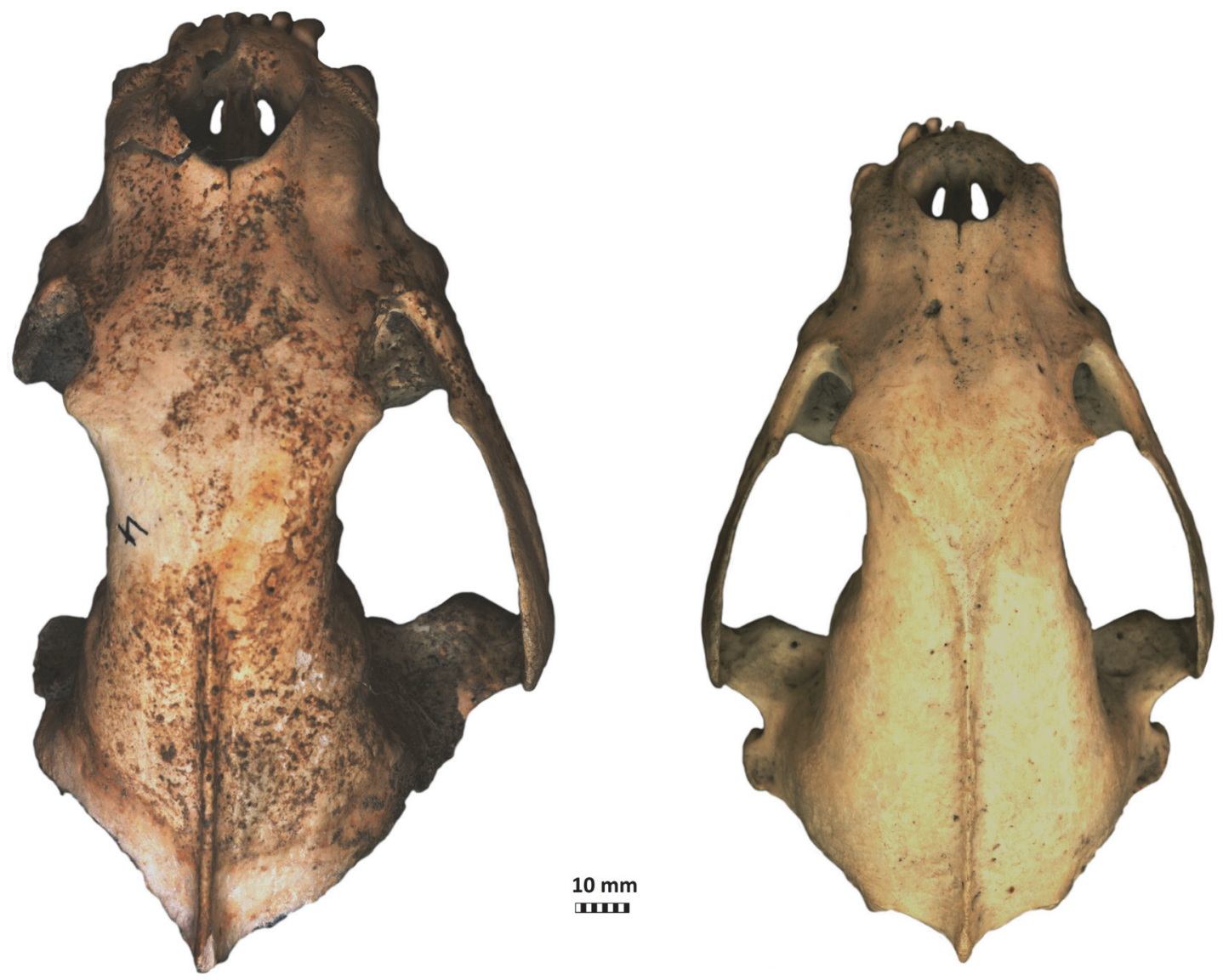

FIGURE 4. Gulo gulo cranium from Solna Jama Cave (JSJ/Gg/1-1) in dorsal view (left) compared with a cranium from a large modern male from Scandinavia (right) from collection of Natural History Museum University of Wrocław (coll. no. M/500328). Scale bar equals $10 \mathrm{~mm}$.

$\mathrm{mm}$ (left); P2-B, $9.49 \mathrm{~mm}$ (right), $6.68 \mathrm{~mm}$ (left); P3-L, $13.25 \mathrm{~mm}$ (right), $13.27 \mathrm{~mm}$ (left); P3-Ba, $7.33 \mathrm{~mm}$ (right), $7.37 \mathrm{~mm}$ (left); P3-Bp, $8.68 \mathrm{~mm}$ (right), $8.73 \mathrm{~mm}$ (left); P4-L, $25.16 \mathrm{~mm}$ (right), $25.18 \mathrm{~mm}$ (left); P4-Ba, $14.19 \mathrm{~mm}$ (right), 14.36 $\mathrm{mm}$ (left); P4-Bp, $10.38 \mathrm{~mm}$ (right); M1-L1, 9.59 $\mathrm{mm}$ (right), $9.36 \mathrm{~mm}$ (left); M1-L2, $7.39 \mathrm{~mm}$ (right), $6.99 \mathrm{~mm}$ (left); M1-L3, $8.52 \mathrm{~mm}$ (right), $8.47 \mathrm{~mm}$ (left); M1-B, $16.14 \mathrm{~mm}$ (right), $15.98 \mathrm{~mm}$ (left). Mandible (JSJ/Gg/1-2/3): i3-L, $5.95 \mathrm{~mm}$ (right); i3B, $6.28 \mathrm{~mm}$ (right); p1-L, $5.08 \mathrm{~mm}$ (left); p1-B, 4.63 $\mathrm{mm}$ (left); p2-L, $7.92 \mathrm{~mm}$ (right); p2-B, $6.11 \mathrm{~mm}$ (right); p3-L, $9.97 \mathrm{~mm}$ (right), $9.91 \mathrm{~mm}$ (left); p3-Ba, $6.04 \mathrm{~mm}$ (right), $6.01 \mathrm{~mm}$ (left); p3-Bp, $7.78 \mathrm{~mm}$ (right), $7.89 \mathrm{~mm}$ (left); p4-L, $14.57 \mathrm{~mm}$ (right); p4$\mathrm{Ba}, 6.98 \mathrm{~mm}$ (right); p4-Bp, $9.94 \mathrm{~mm}$ (right); m1-L, $26.41 \mathrm{~mm}$ (right), $26.47 \mathrm{~mm}$ (left); m1-L-tri, 20.48 $\mathrm{mm}$ (right), $20.63 \mathrm{~mm}$ (left); m1-L-tal, $5.06 \mathrm{~mm}$ (right), $5.12 \mathrm{~mm}$ (left); m1-B-tri, $12.59 \mathrm{~mm}$ (right), $12.64 \mathrm{~mm}$ (left); m1-B-tal, $8.85 \mathrm{~mm}$ (right), 8.86 $\mathrm{mm}$ (left); m2-L, $5.94 \mathrm{~mm}$ (right); m2-B, $5.82 \mathrm{~mm}$ (right). Postcranial bones: Appendix 8.

Description. A detailed morphometric and morphological analysis allows to classify the found individual as a large, late Pleistocene form. All the remains, and especially the cranium, are very large (Figures 4-6). The specimen from Solna Jama Cave not only considerably exceeds the recent Scandinavian specimens in all skull measurements, but also corresponds to the maximum dimensions of the largest late Pleistocene European individuals. The longitudinal diameter of $\mathrm{C} 1$ crowns of the specimen from Solna Jama is ca. $14.5 \mathrm{~mm}$, while the transverse diameter is ca. 11.5 $\mathrm{mm}$. In recent G. gulo, C1 L for males is 8.9-11.8 $\mathrm{mm}$, with the mean of $10.6 \mathrm{~mm}$, while B C1 is $7.1-$ $9.4 \mathrm{~mm}$, with the mean of $8.2 \mathrm{~mm}$. The respective values for females are 7.3-10.5 $\mathrm{mm}$ (mean $=9.5$ $\mathrm{mm}$ ) for $L$ and $6.3-8.0 \mathrm{~mm}$ (mean $=7.3 \mathrm{~mm}$ ) for $B$ (Döppes, 2001; Marciszak, 2012). The late Pleistocene animals were significantly larger than the 

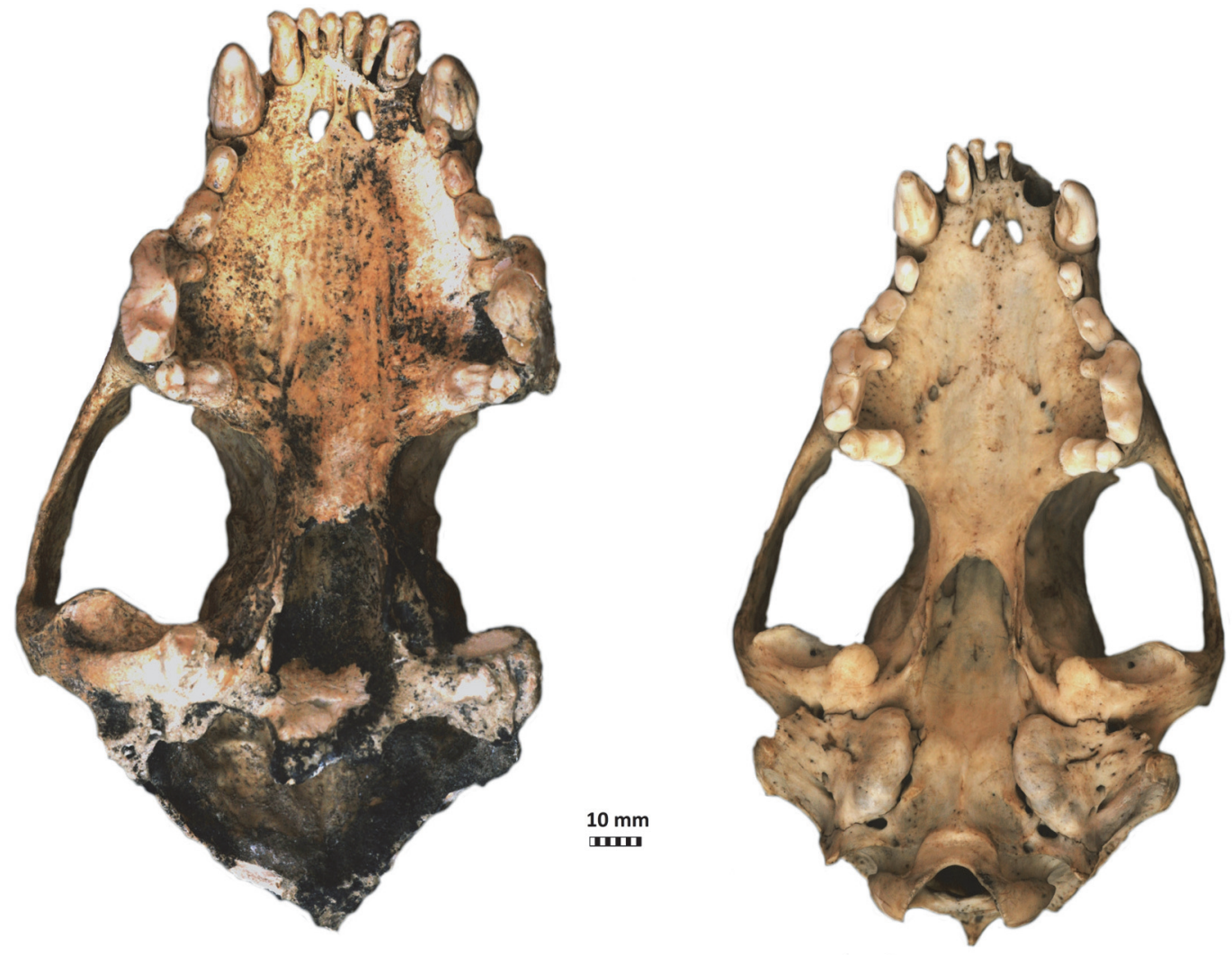

FIGURE 5. Gulo gulo cranium from Solna Jama Cave (JSJ/Gg/1-1) in ventral view (left) compared with a cranium from a large modern male from Scandinavia (right) from collection of Natural History Museum University of Wrocław (coll. no. M/500328). Note particularly powerful dentition of the individual from Solna Jama Cave in comparison with recent G. gulo. Scale bar equals $10 \mathrm{~mm}$.

recent individuals. The analysis showed that canines longer than $11.5 \mathrm{~mm}$ and broader than 9.0 $\mathrm{mm}$ (measured at the crown base) almost certainly belonged to a male. The same is suggested by the other measurements of dental and skeletal remains of G. gulo from Solna Jama. All these features, as well as the poorly expressed cranial sutures and only slightly worn teeth, indicate an adult, particularly large and robust male.

Remarks. The large Gulo gulo from the European late Pleistocene is sometimes assigned to a chronostratigraphical form/subspecies G. gulo spelaea (Goldfuss, 1818), and distinguished from the recent form mainly in its larger size (Goldfuss, 1818b). However, more recent authors regard it as ungrounded and classify it as G. gulo (Döppes, 2001; Marciszak, 2012; Diedrich, 2014). Analysis of large samples from European sites showed that the late Pleistocene G. gulo had on average more robust canines (B/L for fossil G. gulo: $79.5 \mathrm{~mm}, \mathrm{~N}=$ 114; for recent form: $76.2 \mathrm{~mm}, \mathrm{~N}=56$ ). Also, premolars were slightly broader, the talonid of $\mathrm{m} 1$ even narrower than in the modern Gulo (Marciszak, 2012) (Figure 7).

In summary, apart from the pronouncedly larger size, the differences do not seem to be very reliable. Moreover, as demonstrated by the case of the individual from Solna Jama, even clear separation of Gulo populations into two chronosubspecies based on size is impossible. The data indicate that the differences between the large late Pleistocene form and the Holocene/extant populations are big and statistically significant. Overall, large individuals are associated with glaciation periods and smaller ones appear during interglacials. The size of the species follows the Bergmann rule (Pasitschniak-Arts and Larivière, 1995). The size increase in Gulo may also be explained by the severe continental climate with short summers and long, frosty winters that resulted in deforestation of the Sudety Mts. The reduction of plant food supply may have led G. gulo to more active predation and carnivorous foraging. Besides active hunting, it is also a kleptoparasite, and sometimes is even able 


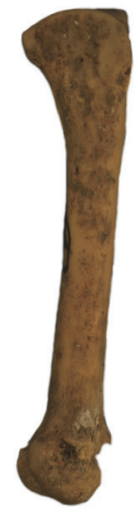

mtcp III

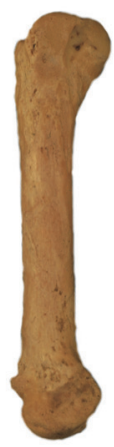

mtcp V

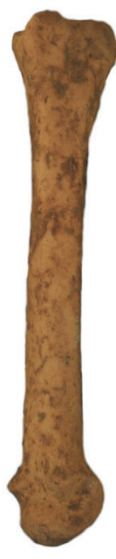

mtts II

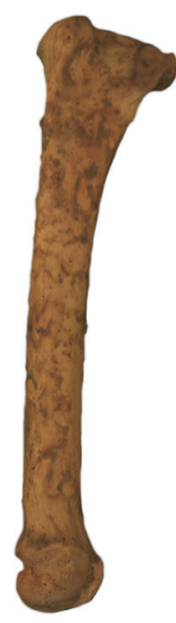

mtts III

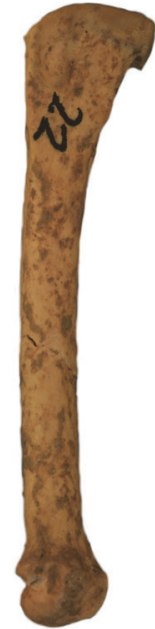

mtts IV

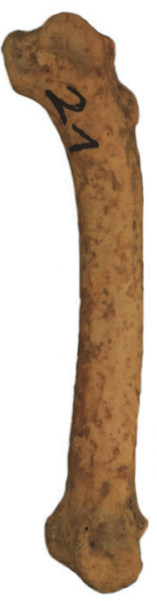

mtts V

\section{$10 \mathrm{~mm}$}

पाIII

FIGURE 6. Metacarpals (mtcp) and metatarsals (mtts) of Gulo gulo from Solna Jama Cave. From left to right: right mtcp III (JSJ/Gg/1-29), left mtcp V (JSJ/GG/1-31), left mtts II (JSJ/Gg/1-33), left mtts III (JSJ/Gg/1-34), left mtts IV (JSJ/Gg/1-35) and right mtts $\vee(J S J / G g / 1-36)$. Scale bar equals $10 \mathrm{~mm}$.

to take a carcass from Canis lupus or Ursus arctos (Pasitschniak-Arts and Larivière, 1995). Its powerful jaws and dentition allow it to crush even thick, solid elk bones. In cold habitats, where carcasses freeze very soon after animal's death, better developed jaw musculature and broader teeth are a necessary equipment. Also a larger body can be of considerable advantage in confrontation with larger animals over food.

Historically, the first record of the species was provided already in 1837, when Pusch (1837) described the posterior part of left P4 from silt of a destroyed cave in Czarnkowa. Later, Zawisza (1882) mentioned a few wolverine remains from the Solutrenian layer in Mamutowa Cave. This was

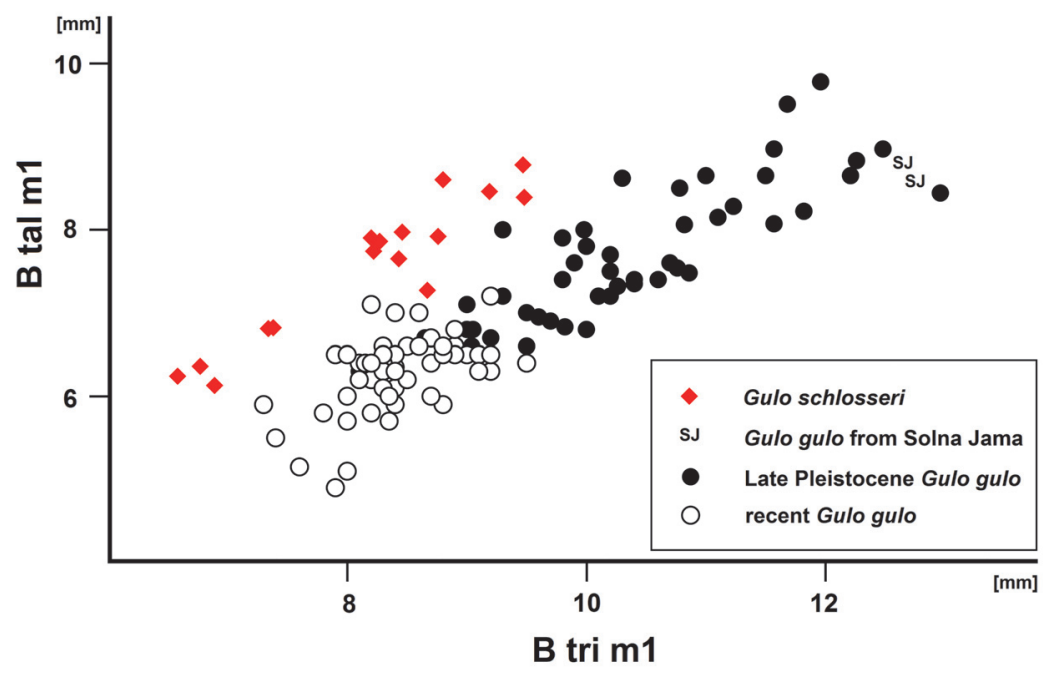

FIGURE 7. Scatter diagram showing the ratio of $\mathrm{m} 1$ trigonid breadth (B tri) to $\mathrm{m} 1$ talonid breadth (B tal) in the forms of Gulo: G. schlosseri and G. gulo. Data from Döppes (2001): late Pleistocene G. gulo and recent G. gulo; data from Marciszak (2012): G. schlosseri and late Pleistocene G. gulo (part). 
followed by a long period without fossil record; no Gulo remains were found by Römer (1883) or Zotz (1939), and only Krukowski (1939) mentioned the species from sediments of Ciemna Cave. After World War II, Kowalski (1959) in his first review of the Pleistocene fauna of Poland listed all three sites. Recently, after re-examining some old German and Polish collections, and due to the new excavations, the list of G. gulo records is significantly extended.

Members of the genus Gulo are present in the fossil material from Poland from the early Pleistocene till the Holocene, and 14 sites with wolverine remains are known (Figure 8 ). The oldest remains, dated as ca. 1.7-1.5 Ma and classified as a gracile, small and primitive G. schlosseri come from Żabia Cave (Nadachowski et al., 2011; Marciszak, 2012). The single, damaged P4 from layer $2 c$ of Kozi Grzbiet (Świętokrzyskie Mts.) (Marciszak, 2012) was also assigned to this species. This find is dated as the early middle Pleistocene, most probable MIS 17 (Kowalski, 2001). The oldest remains of G. gulo come from the lowermost layers of Biśnik Cave (layer 19ad). A single premolar was found in Biśnik Cave, in 2007 (Marciszak et al., 2011). Based on biochronological data, those lowermost layers from both localities are estimated as MIS 10-9 (Krajcarz et al., 2014a; Marciszak, 2014). A few isolated teeth from layers 1 and 3 of Deszczowa Cave are somewhat younger (MIS 6) (Krajcarz and Madeyska, 2010; Krajcarz, 2012). Gulo gulo from all three above-mentioned, late middle Pleistocene sites, are morphologically distinct from those of late Pleistocene age. They represent a more primitive form, of a smaller size and slighter build.

The most numerous records come from the late Pleistocene, when the species was widespread in Europe. Most of them are well dated as the last glacial (MIS 5d-MIS 2). The remains were found in Deszczowa Cave (left mandible with p2$\mathrm{m} 2$ and some postcranial bones belonging to a female, layers 8 and 9, MIS 2) (Wojtal, 2007); Nietoperzowa Cave (fragment of left mandible with p3-p4, layer 4, MIS 3) (Wojtal, 2007; Krajcarz and Madeyska, 2010); Mamutowa Cave (layer 5, MIS 3) (Wojtal, 2007); Ciemna Cave (damaged calcaneus, layer C8, MIS 5) (Krukowski, 1939). The single metatarsals II from layer 6 of Borsuka Cave (Wilczyński et al., 2012) and layer 4 from Cave no. 4 at Birów Hill are both dated as MIS 2. Some of the remains, especially those from the Sudeten sites, have unclear stratigraphic position, however their morphology suggests that they also represent a large, late Pleistocene form. Those finds include

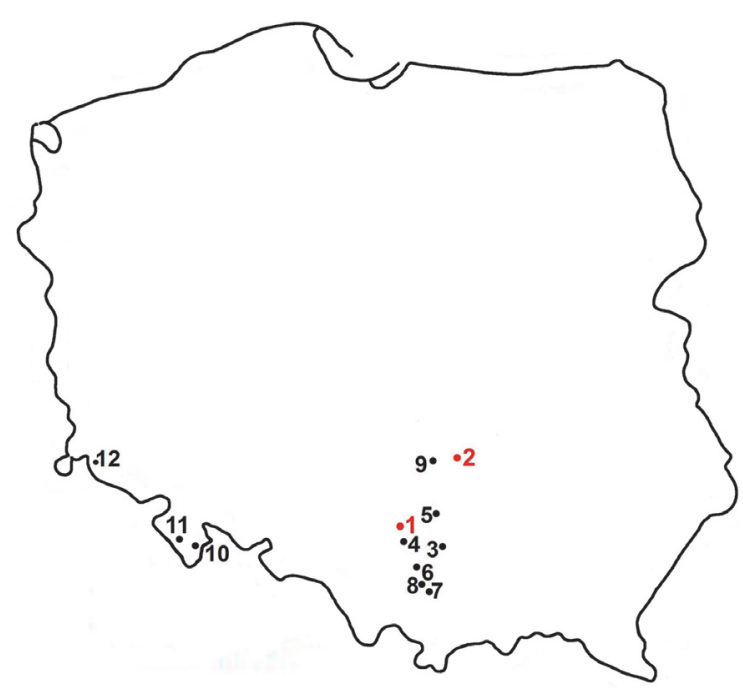

FIGURE 8. Occurrence of members of the genus Gulo in the late Quaternary of Poland (after Marciszak, 2012 and references therein). Red dot: Gulo schlosseri; black dot: G. gulo from late middle Pleistocene (3-5) and late Pleistocene-Holocene (3-12). Localities: 1, Żabia Cave; 2, Kozi Grzbiet; 3, Biśnik Cave; 4, Cave no. 4 on the Birów Hill; 5, Deszczowa Cave; 6, Nietoperzowa Cave, Ciemna Cave; 7, Mamutowa Cave; 8, Borsuka Cave; 9, Cave in Czarkowa; 10, Niedźwiedzia Cave; 11, Północna Duża Cave, Naciekowa Cave; and 12, Solna Jama Cave.

isolated canines from Północna Duża and from layer 21 (trench V) of Niedźwiedzia Cave, as well as a dozen well-preserved long bones and metapodiales from Naciekowa Cave. Similarly, the single premolar from Cave in Czarkowa and the fragment of right mandible with p3-p4 from Mamutowa, Cave, both without stratigraphic context, are most likely of late Pleistocene age. Finally, it can be added that before World War II a complete left foot of a particularly large individual was found in the archaeological site Gródek 2 in the environs of Równe (now Riwne in Ukraine), which was then part of Poland (Loth, 1933). All the above-mentioned sites with G. gulo are of late middle or late Pleistocene age. It seems that the find from Solna Jama is the only reliable, postglacial record of the species from Poland. Till now it was not found in any archaeological Holocene sites in Poland (Wyrost, 1994; Sommer and Benecke, 2004). No remains were found during our detailed revision of the material from those localities (most of them).

Gulo gulo is not inherently a purely "boreal" or "tundra" species (Döppes, 2001). Remains of this species are known from Southeast Europe (Ukraine and Hungary) dated as the Subboreal period, but bones dated as the Middle Ages were 
found only in Northeast Europe (Pribaltica, Fennoscandinavia) (Krakhmalnaya, 1999; Sommer and Benecke, 2004; Marciszak, 2012). Some authors signalled a possible occurrence of G. gulo in Northeast Poland as late as in the nineteenth century (Hoyer, 1937). A few hunting records of the species are known from the last 300 years from areas which once belong to Poland (now W Ukraine): environs of Khmelnytskyi $\left(49^{\circ} 25^{\prime} \mathrm{N}\right.$, 2700'E), Kamianets Podilskyi (48041'N, 26035'E), both dating from the 1700-1750s) and an individual in the vicinity of Ovruch (51019' N, 28048' E, nineteenth century). The last specimens were killed: one just before World War I near Radomyshl (50²9' N,29014'E) and another in the environs of Jarmolińce (49011'N, 26050'E) in 1924 (Kuntze, 1928; Abelentsev, 1968; Daszkiewicz et al., 2005). All these are historical hunting records, and there are no preserved specimens (Lubicz-Niezabitowski, 1934; Tomiałojć, 2003). Although the existence of a small, relict population in historic times cannot be entirely ruled out, it is more probable that those incidental appearances were migrant individuals. Gulo gulo is able to travel long distances, and its daily movements may exceed 30 km (Haglund, 1966; Pulliainen, 1993; PasitschniakArts and Larivière, 1995), while straight-line distances covered in 3 days equal to $64 \mathrm{~km}$ for males and $38 \mathrm{~km}$ for females (Hornocker and Hash, 1981). Sraight-line distances longer than 300-350 km (Gardner et al., 1986) are also known for $G$. gulo. Males are usually more mobile than females, and food availability and sexual maturity are the two major reasons for this behaviour (PasitschniakArts and Lariviere, 1995).

Gulo gulo remains are quite rare in European cave localities. They were found in late Pleistocene sites mostly in the form of bones and were usually heavily outnumbered by other carnivores. The species is not regarded as a typical cave dweller and the almost complete absence of juvenile specimens indicates that caves were not used to raise cubs (Diedrich, 2008). The main reason for accumulation of $G$. gulo bones inside caves seems to be predation; the cave hyena Crocuta crocuta spelaea (Goldfuss, 1823) seems to be the major predator in this case (Diedrich and Copeland, 2010). As remarked by Diedrich (2008, p. 128): "Carnivores were the last prey to be eaten and scavenged", so it is more likely that specimens were killed, brought into caves but in most cases not scavenged. In the case of Solna Jama, Crocuta crocuta spelaea does not seem to be a very likely candidate for G. gulo predator, since it vanished from the territory of
Poland much earlier (before the LGM), and is almost completely absent in the Sudeten sites (Wiśniewski et al., 2009). Besides the scarce material of $C$. lupus, no other large predators, which may have hunted G. gulo, were found. Apart from numerous rodent gnawing marks, some deep gnawing marks were found on the humerus; both its epiphyses were probably bitten off by a large carnivore, most probably Canis lupus (Wojtal, personal commun., 2010). It is very unlikely that they were not fully fused, since the only complete radius bone has all epiphysis and sutures fully fused. At present, $C$. lupus is the major natural enemy of $G$. gulo. Despite the fact that G. gulo actively scavenges on carcasses left by $C$. lupus, it is risky for him. Canis lupus not only competes for food, but also kills G. gulo (Pasitschniak-Arts and Larivière, 1995). Based on these facts it is likely that $C$. lupus was the predator which killed G. gulo.

$$
\begin{aligned}
& \text { Genus MELES Brisson, } 1762 \\
& \text { Meles meles (Linnaeus, 1758) }
\end{aligned}
$$

Specimens. Complete, left c1 (JSJ/Mm/1).

Description. Massive and straight crown of the isolated canine fits well with the morphology of Meles meles canine. The single find from Solna Jama has no stratigraphic context, but almost certainly is not older than the Holocene.

Remarks. It is the most common mustelid in the late Pleistocene assemblages; it occurred through colder and warmer periods (Wolsan, 1989; Sommer and Benecke, 2004; Mallye, 2007; Marciszak, 2012). This species commonly used caves and rock shelters as a place to rest and raise its young. Inhabiting rock crevices or digging burrows in cave deposits, it disturbed the deposit structure. Consequently, finding its remains in a layer does not imply that the age of the remains is the same as or similar to the age of the sediments or other objects found in the same horizon. An example of such behaviour is Mała Cave (South Poland). There, AMS C14 dating clearly indicated Holocene age of the finds that were previously estimated as late Pleistocene. Numerous Me. meles remains were found only in layer 22ab, while the burrow system reached Pliocene layers (Wiszniowska, 1980). The species plays also an active role in the accumulation of debris: various organic materials accumulate in its burrows, sometimes in considerable quantities. Examples of such accumulations are the German sites Pisede 1 and 2, where Me. meles burrows contained huge amounts of fossil and subfossil material dated as the end of the last glaciation and the Holocene (Peters et al., 1973). 
Meles meles is a highly social animal with developed group structure and attached to the place, which the group may use for many generations (more than 100 years). The whole family can build a system of burrows and corridors of several hundred square metres. The presence of juvenile specimens confirms the use of caves as places to rear offspring (Kurtén, 1965a; Wiszniowska, 1980; Mallye, 2007; Marciszak, 2012). Abiotic factors, predators and humans also played a role in the accumulation of Me. meles bones. There are numerous archaeological sites with abundant $M e$. meles remains with traces of human activity (Lüps and Wandeler, 1993; Charles, 2000; Mallye, 2007).

Genus MARTES Pinel, 1792

Martes martes (Linnaeus, 1758)

Specimens. Complete, left radius (JSJ/Ma/1).

Measurements. L, $60.84 \mathrm{~mm}$; pl, $7.38 \mathrm{~mm}$; pB, $4.51 \mathrm{~mm}$; mL, $3.23 \mathrm{~mm}$; $B, 3.36 \mathrm{~mm}$; dL, $9.43 \mathrm{~mm}$. Description. The single radius is proportionally longer and more gracile than the radius of Martes foina (Erxleben, 1777) (Anderson, 1970). The bone measurements and proportions are the most valuable criteria to distinguish the two marten species, while morphological differences are only minute and unreliable (Anderson, 1970). This specimen is within the size range of the recent males of $M a$. martes from Poland with mean $=60.28 \mathrm{~mm}$ (range $=57.74-63.12, N=13$ ) (Marciszak, 2012). The females are smaller, with the mean of $53.04 \mathrm{~mm}$ (range $=51.14-55.21, \mathrm{~N}=12$ ). . The radius is also close to the postglacial and Holocene specimens from Poland (mean $=62.06 \mathrm{~mm}, \mathrm{~N}=18$ ), but distinctly smaller than the late Pleistocene Ma. martes. Radii of more than $80 \mathrm{~mm}$ are known from late Pleistocene layers in the environs of Niedźwiedzia Cave, while those from stratigraphically younger sediments are much smaller, similar to the bone from Solna Jama Cave. It is impossible to determine the sex of the specimen.

Remarks. Detailed revisions of the Pleistocene and Holocene mustelid material from the Polish archaeological and palaeontological sites showed that Martes foina was absent in the fossil record (Wiszniowska, 1989; Sommer and Benecke, 2004; Marciszak, 2012). Kowalski (1959) listed two Pleistocene sites with supposed presence of Ma. foina. Both were cited after other sources, and most probably the author did not see the material. Already Anderson (1970) suspected misidentification and doubted the geological age. Upon revision, the few postcranial bones from Maszycka Cave (Ossowski, 1885) and Wschodnia Cave (Zotz, 1939) labelled as Ma. foina turned out to be
Ma. martes. Martes foina appeared not earlier than the Neolithic period, which is most probably correlated with human colonisation (Anderson, 1970).

\section{Genus MUSTELA Linnaeus, 1758 \\ Mustela eversmanii (Leeson, 1827)}

Figures 9-10

Specimens. Body mandible without ramus, with present p2-m1 (JSJ/Mev/1).

Measurements. Mandible (JSJ/Mev/1): 4, 29.85 $\mathrm{mm}$; , $26.09 \mathrm{~mm}$;, $10.82 \mathrm{~mm}$;, $12.00 \mathrm{~mm}$; $4.11 \mathrm{~mm} ; 12,11.02 \mathrm{~mm} ; 13,5.49 \mathrm{~mm} ; 14,10.20$ $\mathrm{mm} ; 15,5.29 \mathrm{~mm} ; 18,16.15 \mathrm{~mm} ; 19,8.53 \mathrm{~mm}$; $2-$ L, $2.82 \mathrm{~mm}$; p2-B, $1.68 \mathrm{~mm}$; $3-\mathrm{L}, 4.86 \mathrm{~mm}$; $3-\mathrm{Bp}$, $2.32 \mathrm{~mm}$; p4-L, $5.12 \mathrm{~mm}$; p4-Ba, $2.08 \mathrm{~mm}$; $4-B p$, $2.96 \mathrm{~mm}$; m1-L, $9.78 \mathrm{~mm}$; m1-L-tri, $7.41 \mathrm{~mm}$; m1L-tal, $2.24 \mathrm{~mm}$; m1-B-tri, $3.98 \mathrm{~mm}$; m1-B-tal, 2.32 $\mathrm{mm}$; m2-L, $1.34 \mathrm{~mm}$. See Appendix 4 for measured parts.

Description and comparisons. The taxonomy of mustelids, animals of great sex-related, geographical and individual variation, is in many cases still incompletely resolved. Even when well preserved, the specimens are usually difficult to identify, especially when only a single individual is available from the locality. This was the case of the specimen from Solna Jama Cave - right mandible of a fairly large mustelid. The general shape and size clearly indicate a polecat and simultaneously exclude other related taxa like mink or marten. The large size and advanced dental morphology exclude also Mustela stromeri Kormos, 1934 (Kormos, 1934; Marciszak, 2012). At present, two polecat species occur in Poland: Mu. eversmanii and Mu. putorius Linnaeus, 1758 (Wolsan, 1993). Although similar in the morphometric and morphological characters, they differ in many features, which were intensively studied. The most distinctive characters are those of calvarium, but also mandible offers some reliable traits, all of them expressed as ratios. The direct measurements are not useful when determining species of the subgenus Putorius. Mustela eversmanii is on average larger, the mean values of both species are different, but the extreme values are almost the same. The most reliable mandible features are the relative size of $c 1, p 2$ and $\mathrm{m} 2$, size and shape of masseter fossa as well as symphysis and mandibular body robustness (Wolsan, 1993; Marciszak, 2012). The specimen lacks c1 and $\mathrm{m} 2$, but the size of teeth can be estimated based on alveola measurements. Alveola c1 seems to be large and massive, while $\mathrm{m} 2$ alveolar length $(1.34 \mathrm{~mm})$ suggests that the tooth was proportionally very small and narrow. The p2 is also 


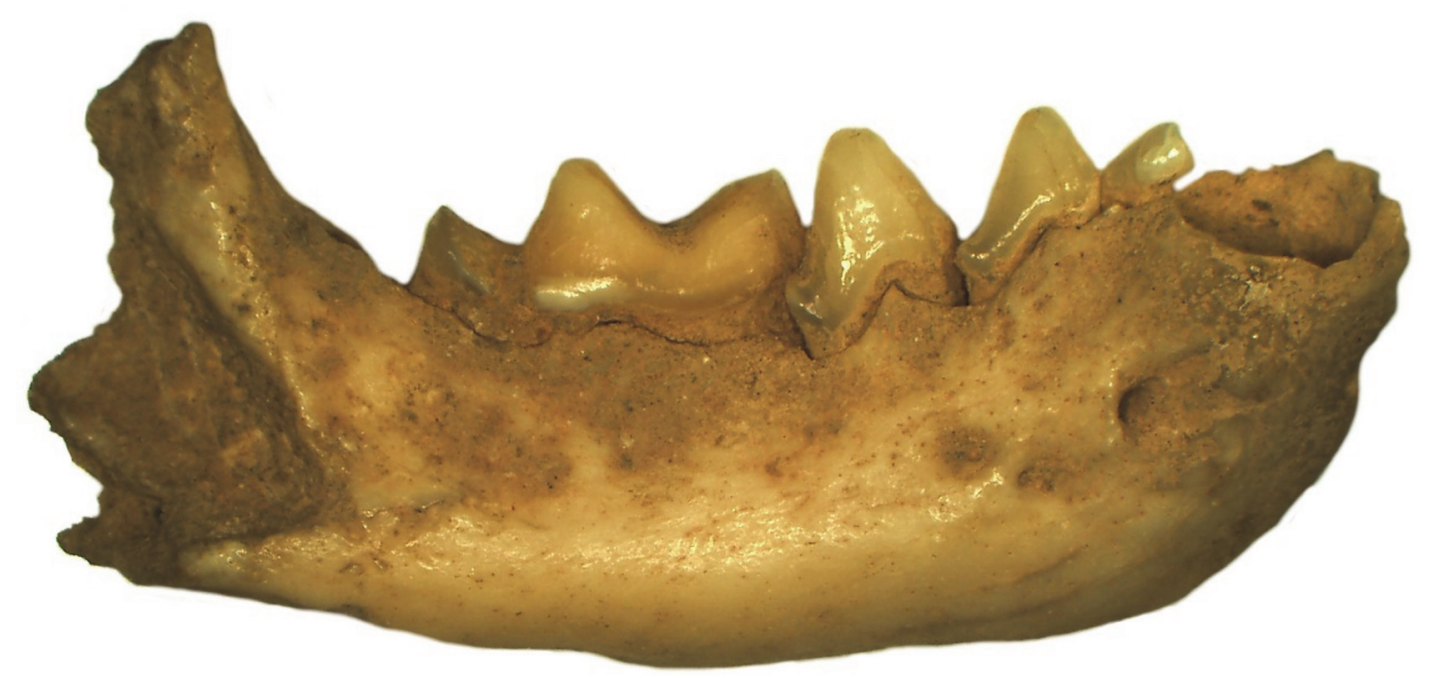

\section{$10 \mathrm{~mm}$}

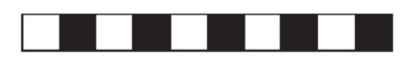

FIGURE 9. Right mandible of Mustela eversmanii (JSJ/Mev/1) from Solna Jama Cave. Note relatively short and robust body mandible and massiveness of the symphysal area. Scale bar equals $10 \mathrm{~mm}$.

reduced and two-rooted, and is comparatively smaller than the average $\mathrm{p} 2$ of $\mathrm{Mu}$. putorius.

The mandible morphology of the specimen also clearly indicates Mustela eversmanii (Figure 9). The mandible body is high and thick, but apparently shorter than in Mu. putorius. In lateral buccal view is very bulky, the lower margin is strongly convex, instead of being curved gently as in Mu. putorius, and the maximum of the curve is located under $\mathrm{m} 1$ paraconid. The ratio of $\mathrm{m} 1$ total length to mandible body height measured between $\mathrm{p} 4$ and $\mathrm{m} 1$ (measurement no. 14) is very useful in species identification. Its mean value for $M u$. eversmanii is $92(\mathrm{~N}=102)$, while for $M u$. putorius the mean is $110(\mathrm{~N}=332)$. The specimen with its ratio of 95.9 is much closer to the eversmanii than to the putorius mean, and the data show a non-characteristic intermediate value (Figure 9). Even the direct measurement no. 14 is quite useful, and most authors agree that values below $8.0 \mathrm{~mm}$ indicate $\mathrm{Mu}$. putorius with high probability. Similarly, the mandible body higher than 9.0-9.5 mm allows to classify the specimen as $M u$. eversmanii. However, research on a large sample of both species showed that the measurement was also correlated with individual age and variation, and some huge individuals with comparatively not very high mandible body are also known (Marciszak, 2012). In the examined mandible the masseter fossa is anteriorly rounded and centrally deep, and reaches the $\mathrm{m} 1 / \mathrm{m} 2$ border. A circular depression occurs on the labial side below the protoconid of $\mathrm{m} 1$, while this character is poorly developed in $M u$. putorius. On the lingual side it displays ridge-like thickenings along the tooth row, and elongate depressions occur below it. The lingual wall of the mandible body in $M u$. putorius is rather uniform in shape, without such structures. The mandible from Solna Jama Cave is very different in the stoutness of its symphysal part from that if $M u$. putorius, and very similar to that of $M u$. eversmanii. The anterior part of the mandible forms a massive and elongated symphysis, in proportion to the large size of the canine alveole. The posterior boundary of the masseter fossa in $M u$. putorius is more rounded and not produced so far anteriorly as in $\mathrm{Mu}$. eversmanii, where it often extends below the trigonid/talonid border, and terminates in an acute angle. Finally, the inferior swelling of the ramus below the masseter fossa in labial view is visible, though only a fragment is preserved. The tooth wear indicates an old individual, and combined with the size indicates a senile, medium-sized male (Figure 10).

Remarks. This mustelid is regarded as a highly specialised big rodent hunter (Heptner and Naumov, 1967; Sickenberg, 1968), whose strong asso- 


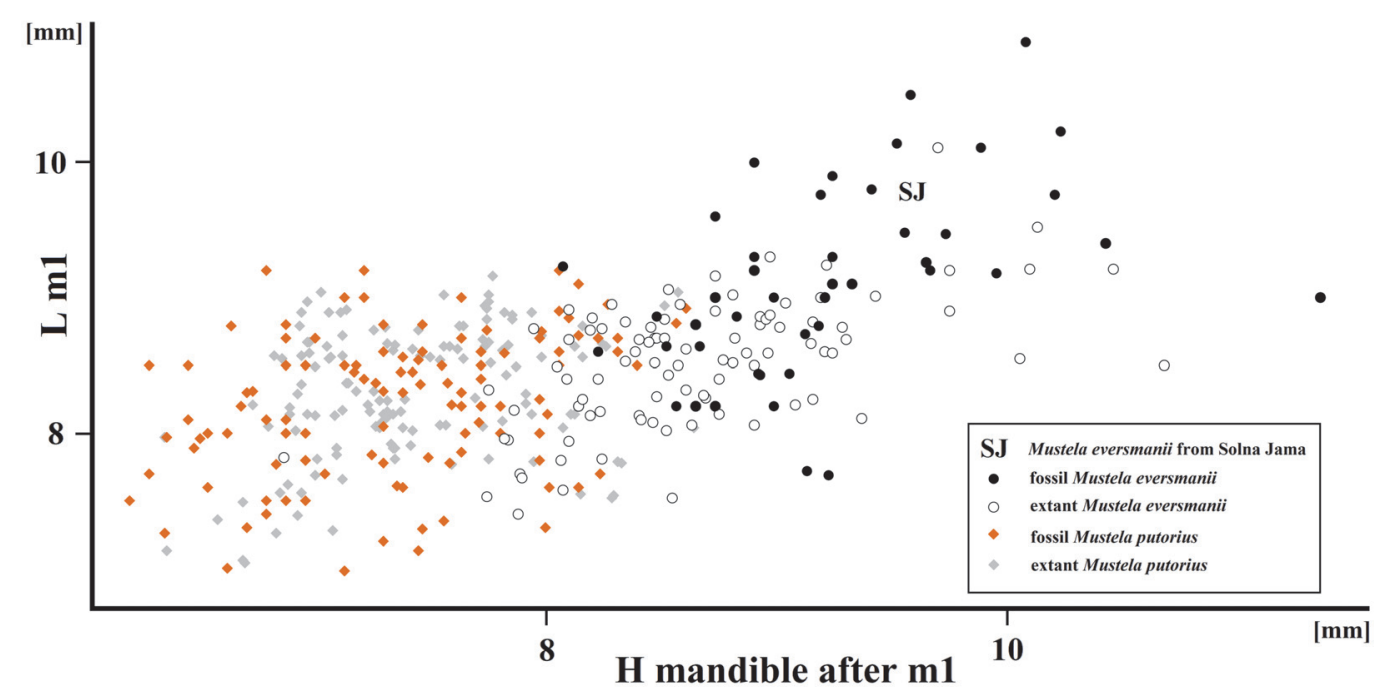

FIGURE 10. Scatter diagram showing the ratio of mandiblar height (measured after $\mathrm{m} 1$ ) to $\mathrm{m} 1$ length in fossil and extant Mustela eversmanii and Mu. putorius. Data from Marciszak (2012) and references therein.

ciation with large, steppe rodents from genus Spermophilus, Cricetus or Gerbillus, was observed in many regions, also Poland (Buchalczyk and Ruprecht, 1975; Kurtén, 1968; Wolsan, 1993; Šálek et al., 2013). The same association was documented in many late middle and late Pleistocene sites, where the same layers held remains of Mustela eversmanii and those large, steppe rodents (Kurtén, 1968; Sickenberg, 1968; Marciszak, 2012). In Solna Jama Cave there is no evidence for such association. However, their absence does not necessarily mean that these rodents were not available to the steppe polecat in the environs of the cave. It is very likely that the fossil record from the site is incomplete, since much deposit remains to be excavated.

Although rodents of the genus Spermophilus are the main prey for this species in many regions, they are not indispensable to the polecat. Their presence or absence in particular areas need not be a crucial for the Mustela eversmanii existence. In many regions local populations subsist on different prey, like rodents from genus Cricetus and Microtus in Hungary (Lanszki and Heltai, 2007), Rhombomys opimus (Lichtenstein, 1823) in Kazakhstan (Heptner and Naumov, 1967) and members of the genus Ochotona Link, 1795 and Microtus as well as family Spalacidae Gray, 1821 in China ( $\mathrm{Li}$ et al., 2012). In areas where, like for example in southeastern Poland, populations of Spermophilus suslicus (Güldenstaedt, 1770) have decreased dramatically in the last 50 years, Cricetus cricetus seems to be one of the most important prey items. Based on the fossil assemblage, it is probable that the late Pleistocene $M u$. eversmanii in Poland hunted mainly Lemmus lemmus, Dicrostonyx gulielmi, Clethrionomys glareolus, Microtus agrestis, Mi. arvalis and Mi. gregalis (Marciszak, 2012; Krajcarz et al., 2014b). Remains of some of these rodents where also found in Solna Jama Cave.

This is the first record of Mustela eversmanii from the Sudeten caves, and one of the few from the Polish Pleistocene. The oldest Pleistocene record, dated as MIS 10-9, comes from the lowermost layers 19ad from Biśnik Cave, where a small, primitive $M u$. eversmanii was found. The species is present in the Eemian sediments of Biśnik Cave (layer 13), where it also occurs in layers dated as the late Pleistocene (Marciszak et al., 2011; Marciszak, 2012). Apart from these sites, Mu. eversmanii was only found in layer 15/12 in Obłazowa Cave (MIS 3) (Marciszak, 2012) and layer C of Stajnia Cave. Finally, recently Krajcarz et al (2014b) described in detail a left mandible of a modernsized male from layer B2 of Deszczowa Cave. Earlier excavations in Deszczowa Cave (Cyrek et al., 2000 ), layer 7 , yielded a still undescribed left mandible and three long bones of a great male. These six sites are till now the only confirmed paleontological Polish records of the species. The individual mentioned from Cave no. 4 on Birów Hill (Muzolf et al., 2009), after detailed morphometric and morphological analysis, proved to be an atypical specimen of Mu. putorius (Marciszak, 2012).

Also, the history of recent distribution of the species is poorly documented. The individuals which occur in Southeast Poland have spread from 
the main Ukrainian population, which is represented by the nominate subspecies Mustela eversmanii eversmanii (Wolsan, 1993). The present boundaries of Poland were established after World War II, and until the 1970s Mu. eversmanii was not recorded inside the territory of Poland. Also in the past, none of the researchers (Gloger, 1833; Pax, 1925) who studied the Silesian fauna mentioned the presence of the species north of the Sudeten arch (Kostroň, 1948). Although some authors suggested its possible occurrence in Southeast Poland, it is absent in the faunal list (Buchalczyk, 1964). In the 1970s and 1980s the species was recorded from Southeast Poland several times (Buchalczyk and Ruprecht, 1975; Ruprecht, 1985; Głowaciński and Profus, 1987). Now very little is known about the present status of the species. It is regarded as near threatened in the Polish Red List, but during the last 25 years there were no reliable records. However, the most recent paper on $M u$. eversmanii status in Europe lists the species as appearing sporadically in few xerothermic patches (Śálek et al., 2013).

\section{Mustela nivalis Linnaeus, 1766 Figures 11-13}

Specimens. Skull with damaged neurocranium, and present left P3-M1 and right P4-M1 (JSJ/Mnv/ 1 ); complete mandible with present $\mathrm{p} 2$ and $\mathrm{p} 4-\mathrm{m} 2$ (JSJ/Mnv/2).

Measurements. Skull (JSJ/Mnv/1): 1, $29.42 \mathrm{~mm}$; 4, $9.45 \mathrm{~mm}$; 6, $9.94 \mathrm{~mm}$;, $4.82 \mathrm{~mm} ; 8,9.53 \mathrm{~mm}$; 9, $11.78 \mathrm{~mm} ; 10,8.63 \mathrm{~mm} ; 11,6.27 \mathrm{~mm} ; 12,15.61$ $\mathrm{mm} ; 13,2.71 \mathrm{~mm} ; 14,5.79 \mathrm{~mm} ; 15,9.12 \mathrm{~mm} ; 16$, $9.12 \mathrm{~mm} ; 17,3.12 \mathrm{~mm} ; 18,7.78 \mathrm{~mm} ; 19,7.12 \mathrm{~mm}$; 25, $3.12 \mathrm{~mm}$; 26, $9.09 \mathrm{~mm}$; 32, $8.53 \mathrm{~mm}$; P3-L, $1.77 \mathrm{~mm}$; P3-Bp, $0.82 \mathrm{~mm}$; P4-L, $3.34 \mathrm{~mm}(\mathrm{R})$, $3.32 \mathrm{~mm}$ (L); P4-Ba, 1.59 mm (R, L); P4-Bp, 1.09 $\mathrm{mm}(\mathrm{R}), 1.11 \mathrm{~mm}(\mathrm{~L})$; $\mathrm{M} 1-\mathrm{L} 1,1.29 \mathrm{~mm}(\mathrm{R}), 1.31$ $\mathrm{mm}(\mathrm{L}) ; \mathrm{M} 1-\mathrm{L} 2,0.84 \mathrm{~mm}(\mathrm{R}), 0.81 \mathrm{~mm}(\mathrm{~L}) ; \mathrm{M} 1-\mathrm{L} 3$, $1.02 \mathrm{~mm}(\mathrm{R}), 1.05 \mathrm{~mm}(\mathrm{~L})$; M1-B, $1.51 \mathrm{~mm}(\mathrm{R})$, $2.48 \mathrm{~mm}(\mathrm{~L})$. Mandible (JSJ/Mnv/2): 1, $16.21 \mathrm{~mm}$; 2, $15.08 \mathrm{~mm}$;, $10.52 \mathrm{~mm} ; 4,10.42 \mathrm{~mm} ; 5,8.81$ $\mathrm{mm} ; 6,4.71 \mathrm{~mm} ; 7,4.41 \mathrm{~mm} ; 8,1.97 \mathrm{~mm} ; 9,5.34$ $\mathrm{mm} ; 10,7.48 \mathrm{~mm} ; 11,9.08 \mathrm{~mm} ; 12,2.65 \mathrm{~mm} ; 13$, $1.32 \mathrm{~mm} ; 14,2.73 \mathrm{~mm} ; 15,1.34 \mathrm{~mm} ; 16,1.29 \mathrm{~mm}$; $17,3.62 \mathrm{~mm} ; 18,5.42 \mathrm{~mm}$; 19, $2.18 \mathrm{~mm}$; p2-L, $1.19 \mathrm{~mm}$; p2-B, $0.74 \mathrm{~mm}$; p4-L, $1.96 \mathrm{~mm}$; p4-Ba, $0.94 \mathrm{~mm}$; p4-Bp, $1.05 \mathrm{~mm}$; m1-L, $3.94 \mathrm{~mm}$, m1-Ltri, $2.78 \mathrm{~mm}$, m1-L-tal, $1.19 \mathrm{~mm}$; m1-B-tri, 1.33 $\mathrm{mm}$; m1-B-tal, $1.25 \mathrm{~mm}$; m2-L, $0.88 \mathrm{~mm}$; m2-B, $0.90 \mathrm{~mm}$. See Appendices 3 and 4 for measured parts.

Remarks. The two remains belonged to a female (calvarium) (Figure 11) and a male (mandible), both adult. Males are always considerably larger, and the late Pleistocene populations were no exception. Apart from sexual dimorphism, Mustela nivalis body size also varies under the effect of many other factors: local habitats, climatic conditions, snow cover, prey density and many others (Abramov and Baryshnikov, 2000; King and Powell, 2007). Mustela nivalis do not follow the Bergmann rule, and smaller individuals are usually found in cooler areas, while larger individuals occur in warmer places.

However, this is not as obvious as previously thought, and much more complicated. At present, $M u$. nivalis has an extremely wide circumboreal and Holarctic distribution, with many subspecies and forms of different size and body proportions (Marciszak and Socha, 2014, p. 260, figure 3). These differences are even larger than those between populations of $\mathrm{Mu}$. erminea (Heptner and Naumov, 1967; King and Powell, 2007). Mustela nivalis occurs throughout the European late Pleistocene, and detailed studies on the Polish material show that both sexes were on average significantly smaller than the modern individuals (Figures 1213) (Marciszak, 2012; Marciszak and Socha, 2014).

The calvarium is the only complete weasel skull from the Polish sites known till now. The skull from layer 13 of Nietoperzowa Cave, dated as MIS $5 e$ and described by Wójcik (1974, p. 79-80, 85, tables $\mathrm{I}$ and $\mathrm{V}$ ) and belonged in fact to a small female of $\mathrm{Mu}$. erminea. The morphology of the specimen from Solna Jama Cave clearly indicates Mu. nivalis, and its measurements are even smaller than the smallest female measured from Poland. The total length of the skull is $29.40 \mathrm{~mm}$, while the respective values for the recent Polish males is mean $=40.67 \mathrm{~mm}$ (range $=37.00-49.20$, $\mathrm{N}=115$ ), and for the females is mean $=32.88 \mathrm{~mm}$ (range $=30.20-35.31, \mathrm{~N}=65$ ). This dwarf size, together with proportionally gracile build (Figures 11-12) indicate that the specimen represents $M u$. nivalis pygmaea (Allen, 1933), which now occurs only in Siberia (sensu Abramov and Baryshnikov, 2000).

The mandible individual from Solna Jama Cave is a medium-sized male, typical of postglacial period; it differs from the female in the more pronounced broadening of $\mathrm{m} 1$ crown at the base of protoconid. With its length of $\mathrm{m} 13.94 \mathrm{~mm}$, the male falls into the upper part of size range of the late Pleistocene males (Figure 13), but is considerably smaller than the modern $M u$. nivalis from Poland (for males: mean $=4.60 \mathrm{~mm}$, range $=4.02-$ 

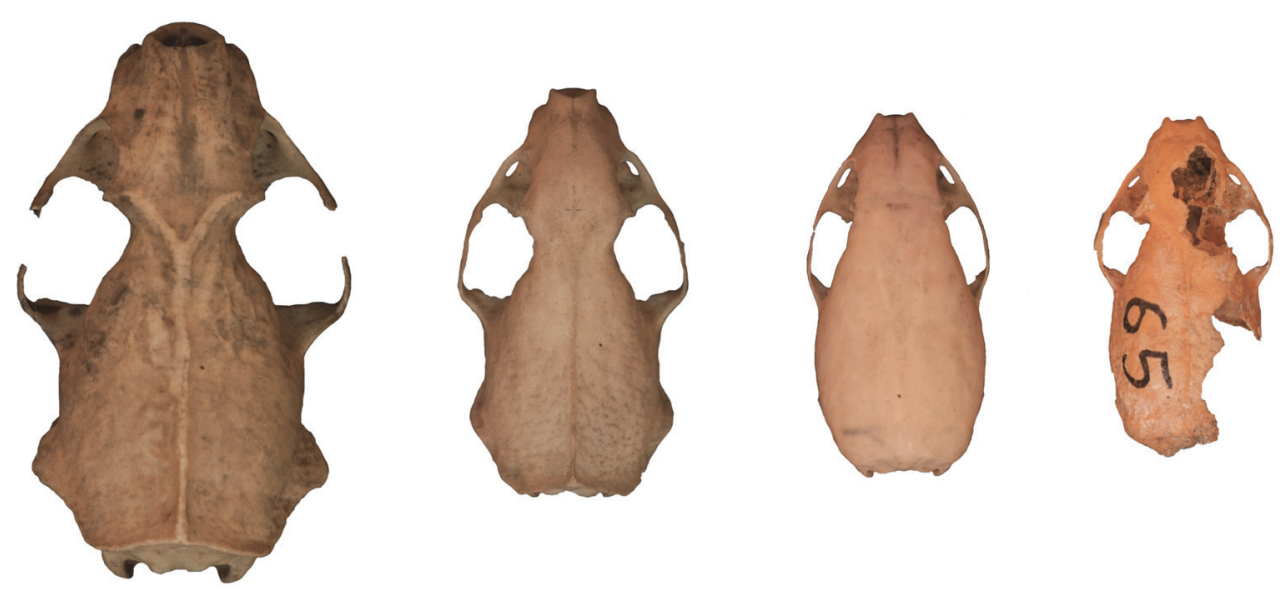

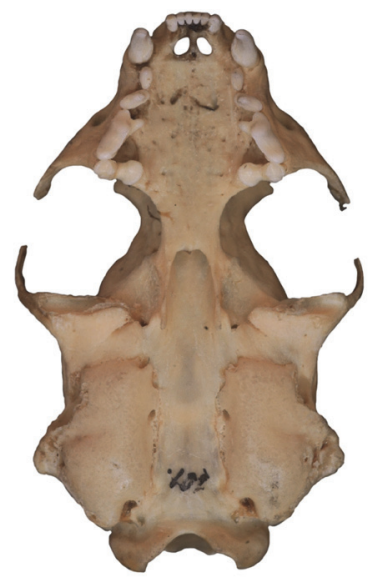

1

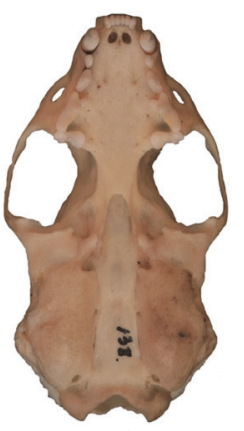

2

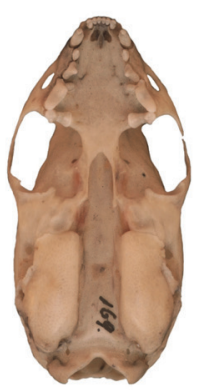

3

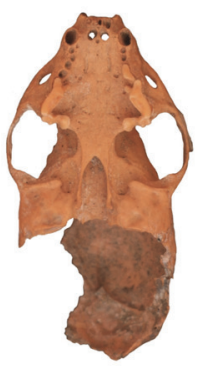

4

$10 \mathrm{~mm}$

प्रणप

FIGURE 11. Skulls of Mustela nivalis from Poland: recent specimens (1-3) and the fossil from Solna Jama Cave (4). 1, robust, adult male; 2 , adult female; 3, young, adult female; and 4, adult female. Note fully developed sagittal crest in individual from Solna Jama Cave, indicating fully mature age. Scale bar equals $10 \mathrm{~mm}$.

5.02, $\mathrm{N}=283$; for females: mean $=3.69 \mathrm{~mm}$, range = 3.32-4.14, N = 114) (Marciszak, 2012).

Remarks. The minute fossil form, described earlier by some authors, for example van den Brink (1957) or Allen (1933) as Mustela nivalis minuta (Pomel, 1853) and $M u$. rixosa Bangs, 1896, are most probably only small, local variations of nivalis or the pygmaea form (Wójcik, 1974; Marciszak, 2012). The dwarf individuals from the late Pleistocene reflect the evolutionary and ecological plasticity of the species. In the middle Pleistocene the climate cooling progressed due to the extensive glaciation. This, combined with the body structure ensuring only minimum protection against heat loss, meant that $M u$. nivalis faced the need to adapt to the rapidly changing climatic conditions. This resulted in a progressive reduction of the body size and in most parts of Europe to dwarfing. This process reached its peak in the coolest periods of the late Pleistocene. The small mustelids reduced their size to an extent that was necessary and economic from the point of view of energy. They were small enough to move freely and hunt for rodents in a maze of underground corridors. At the same time they were large enough to effectively kill their prey, and the amount of food consumed ensured positive energy balance (King, 1989; Szafrańska et al., 2006; King and Powell 2007). Today, the co-existence of 


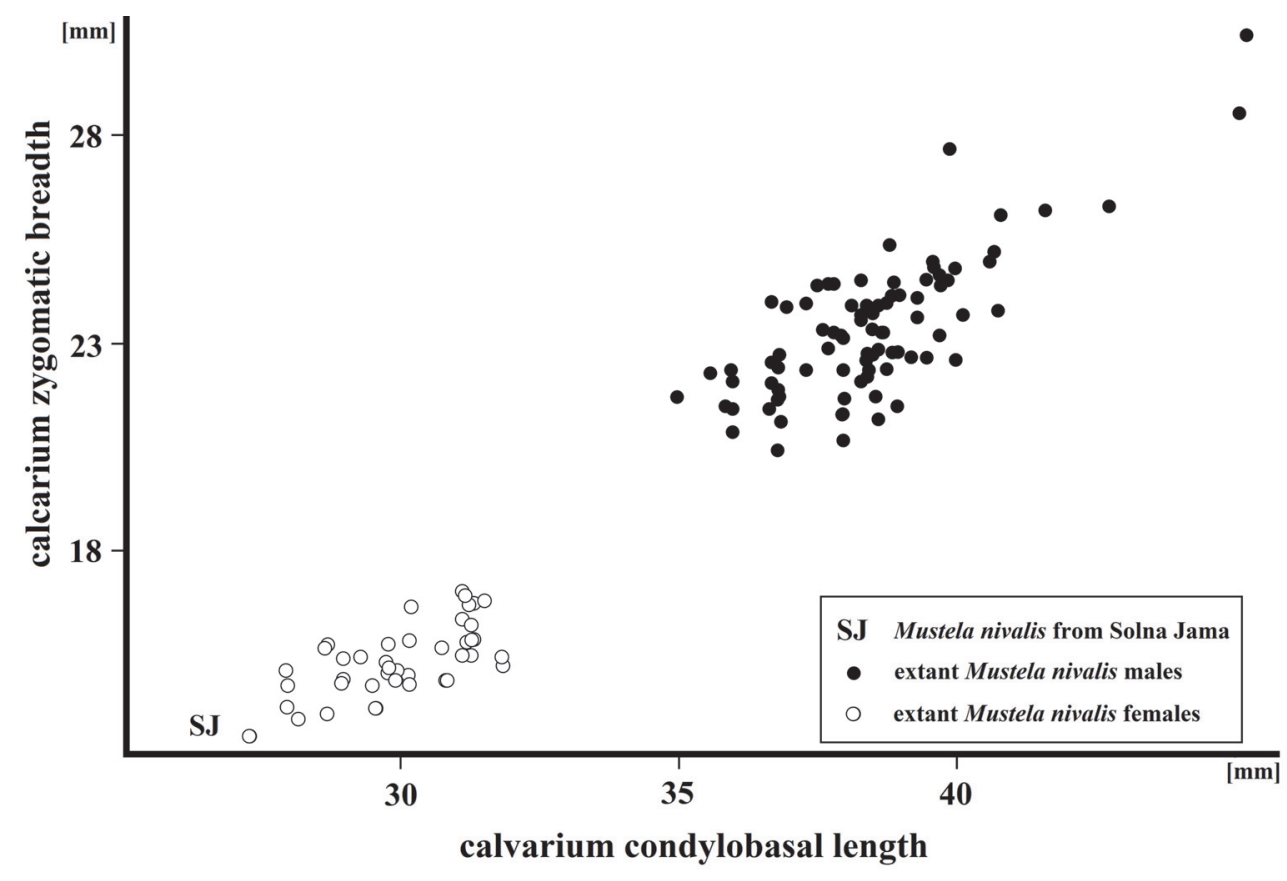

FIGURE 12. Scatter diagram showing the ratio of total calvarium length to zygomatic breadth in extant Mustela nivalis from Poland, compared with the fossil specimen from Solna Jama Cave.

small- and large-sized forms in some areas can be associated with adaptation to local habitats. The emergence of these ecotypes was a response to species-specific, local environmental conditions. Small individuals are found in mountainous regions (Alps, Carpathians, Caucasus), or in areas with a harsh (often continental) climate regime, such as Siberia (Abramov and Baryshnikov, 2000). It has to do not only with thermoregulation and a limited number of potential prey, but also the reproduction strategy. Females of the small and dwarf subspecies are capable of producing and raising two litters within six months, whereas in the larger subspecies only one litter is produced during that time. Faster maturation of the females is a response to the short summer in the northern hemisphere (Abramov and Baryshnikov, 2000).

King and Powell (2007) found a correlation between the duration of the snow cover and Mustela nivalis body size based on condylobasal length $(\mathrm{CBL})$ : the longer the snow cover lasts, the smaller the skull CBL. However, this relationship is much more complicated than previously thought. This is due to the fact that the low temperature, which is the main factor responsible for the fluctuations in weasel body size, it is not always related to the amount of precipitation and the duration of snow cover, as exemplified by the cold steppes of central Asia (Hernández Fernández, 2001).

Today Mustela nivalis is a specialised hunter of small rodents, which can account for up to $90 \%$ and, during mass appearance, even close to $100 \%$ of food (Jędrzejewska and Jędrzejewski, 2001; King and Powell, 2007). The abundance of rodents is subject to strong fluctuations. Like in $M u$. erminea, the very pronounced sexual dimorphism of $M u$. nivalis has to influence the prey size selection. The males, being larger and more powerful, often choose a larger-sized prey, such as a small Oryctolagus, Rattus or Cricetus cricetus, while the females feed mainly on vole-sized rodents (Reichstein, 1993b; Jędrzejewska and Jędrzejewski, 2001; King and Powell, 2007).

The massiveness increase in the evolution of Mustela nivalis teeth, compared to the ermine, is less pronounced. This is due to the fact that $M u$. nivalis specialises in hunting small rodents, whose size is generally comparable to the weasel size. The bones of these animals (especially the skull bones) are not too thick, so it is not necessary to have extremely massive teeth to pierce the hard bones of the prey. In contrast to Mu. nivalis, $M u$. erminea (especially males) often kills prey much larger than itself (e.g., lagomorphs). Their thicker 


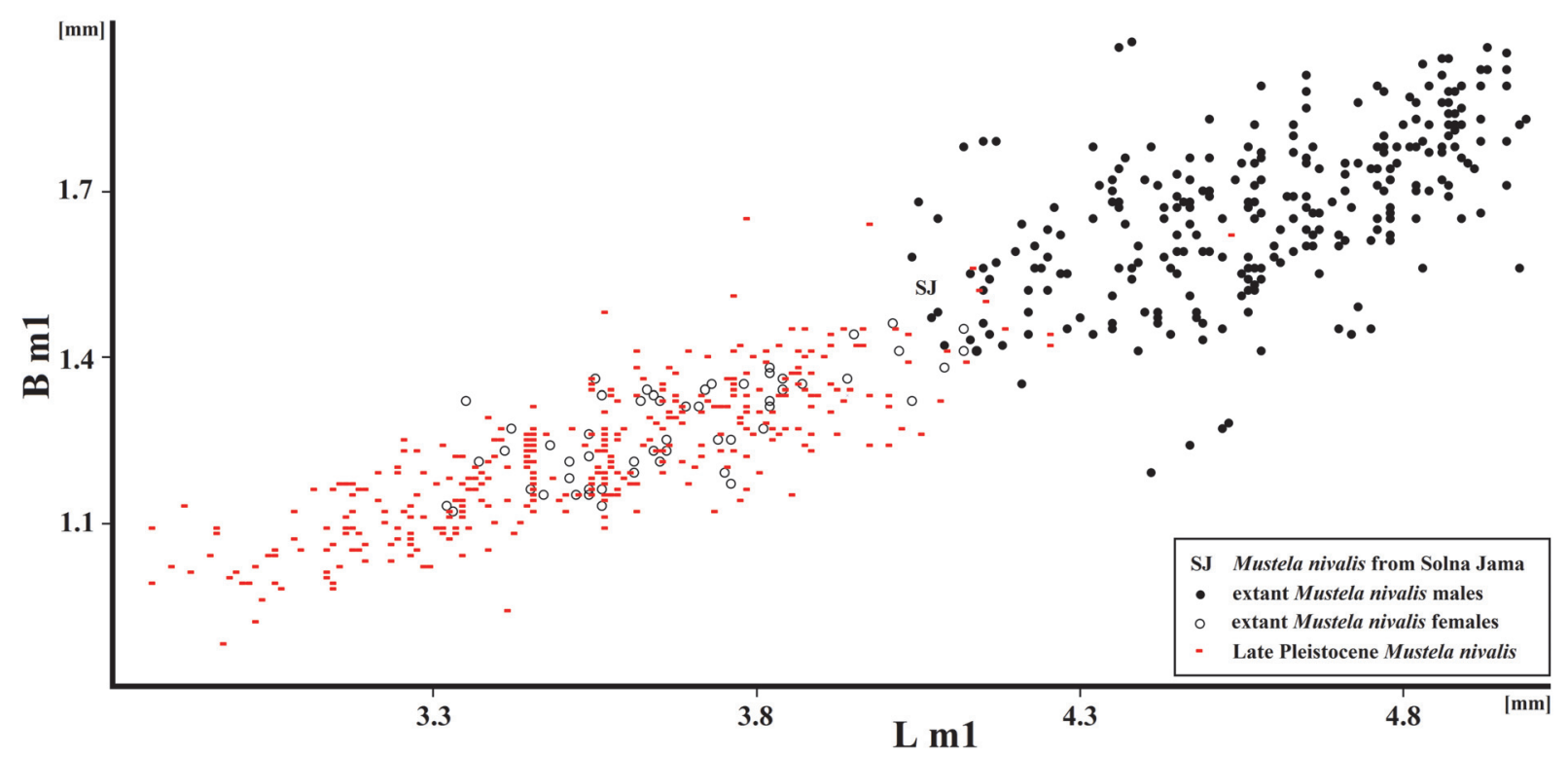

FIGURE 13. Scatter diagram showing the ratio of lower carnassial (m1) length (Lm1) and breadth (B m1) in late Pleistocene and Recent Mustela nivalis from Poland. The Solna Jama Cave specimen displays a moderately large size, with the length of $\mathrm{m} 1$ less than $4 \mathrm{~mm}$, typical of the late Pleistocene and postglacial period.

skeleton requires significantly more powerful jaws and teeth adapted to withstand the strong mechanical stress (Heptner and Naumov, 1967; Reichstein, 1993a; King and Powell, 2007).

The large number of Mustela nivalis remains in some sites (Biśnik Cave, Stajnia Cave, Obłazowa 1 Cave, Aven 1 Abimés de la Fage, Istallöskö, Puskaporos) is associated with the activity of predators and humans (Kormos, 1911; Jánossy, 1955; Hugueney, 1975; Marciszak, 2012). As a smaller animal, with smaller territories and greater density, as well as the lack of black tail tip to disconcert the attacker, $M u$. nivalis falls prey to predators more often than $\mathrm{Mu}$. erminea (King and Powell, 2007). Studies in the Białowieża Forest show that $M u$. nivalis remains are found with an average frequency of $0.5 \%$ in pellets and faeces of birds and mammals. The registered mortality was $87 \%$ within 6 months (Jedrzejewska and Jędrzejewski, 2001).

Family FELIDAE Fischer von Waldheim, 1817 Genus FELIS Linnaeus, 1758

Felis silvestris Schreber, 1777

Specimens. Right mandible without ramus and with c1-m1 (JSJ/Fs/1).

Measurements. Mandible (JSJ/Fs/1): 4, 42.68 $\mathrm{mm} ; 5,36.42 \mathrm{~mm} ; 6,6.58 \mathrm{~mm} ; 7,23.53 \mathrm{~mm}$; , $14.46 \mathrm{~mm} ; 9,5.65 \mathrm{~mm} ; 11,28.86 \mathrm{~mm} ; 12,18.72$ $\mathrm{mm} ; 13,6.21 \mathrm{~mm} ; 16,11.67 \mathrm{~mm} ; 17,4.83 \mathrm{~mm}$; 1 L, $6.03 \mathrm{~mm}$; c1-B, $3.74 \mathrm{~mm}$; p3-1, $6.48 \mathrm{~mm}$; $33-2$, $4.32 \mathrm{~mm}$; $33-3,4.57 \mathrm{~mm}$; $33-4,2.43 \mathrm{~mm}$; p3-5,
$2.92 \mathrm{~mm} ; \mathrm{p} 4-1,8.45 \mathrm{~mm} ; \mathrm{p} 4-2,4.54 \mathrm{~mm} ; \mathrm{p} 4-3$, $5.37 \mathrm{~mm} ; \mathrm{p} 4-4,2.95 \mathrm{~mm} ; \mathrm{p} 4-5,3.64 \mathrm{~mm} ; \mathrm{m} 1-1$, $9.82 \mathrm{~mm} ; \mathrm{m} 1-2,4.71 \mathrm{~mm} ; \mathrm{m} 1-3,5.11 \mathrm{~mm} ; \mathrm{m} 1-4$, $4.92 \mathrm{~mm} ; \mathrm{m} 1-5,6.33 \mathrm{~mm} ; \mathrm{m} 1-6,3.42 \mathrm{~mm} ; \mathrm{m} 1-7$, $4.31 \mathrm{~mm}$. See Appendices 5-7 for measured parts. Description. With the length of $\mathrm{m} 1$ of ca. $9.8 \mathrm{~mm}$ and the quite massive mandible body, the individual from Solna Jama was classified as a big male. The morphology is characteristic of the recent European form of the nominate subspecies. Contrary to some specimens, the lower margin of the mandible body is almost straight and lacks the curve under $\mathrm{p} 4$. The diastema is long (length: 6.58 $\mathrm{mm}$ ) and is within the range of variation of different modern populations, where the average values are ca. 5.8-6.3 mm (Kurtén, 1965b). These measurements considerably exceed those of the lower and middle Pleistocene forms, for which a proportionally short diastema is regarded as diagnostic (Kurtén, 1965b; Barycka, 2008). All the preserved cheek teeth are proportionally low-crowned and narrow. The protoconid of $\mathrm{p} 4$ is long, but quite low, instead of being short and high as in the earlier forms (Kurtén, 1965b).

Remarks. Felis silvestris is very rarely found in the Pleistocene Central European deposits. Most of the so-called "fossil" individuals, whose age was estimated based on biostratigraphical or other indirect evidence, in most cases turned out to be postglacial subfossils. The same conclusion was reached during a detailed revision of the Polish 


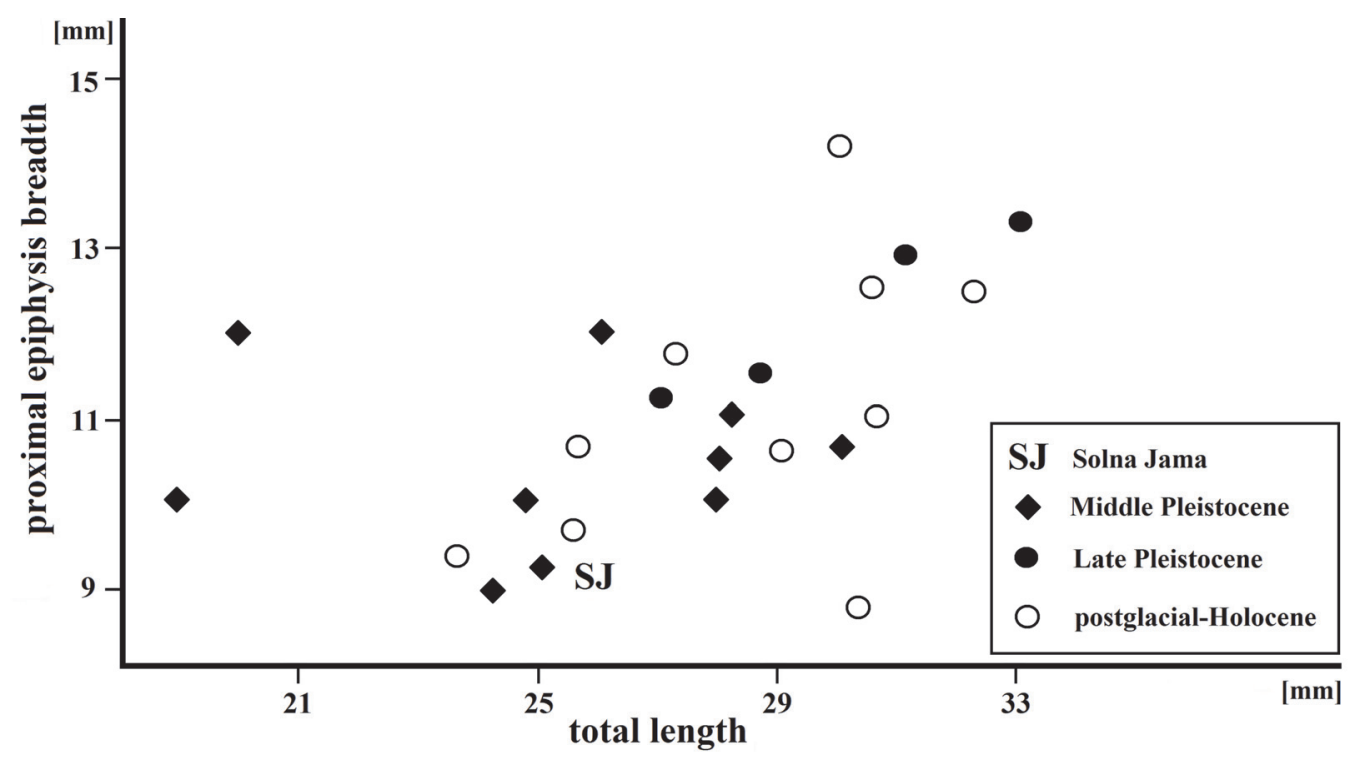

FIGURE 14. Scatter diagram showing the ratio of total length to proximal epiphysis breadth in late pleistocene-holocene Capreolus capreolus phalanx II. Middle Pleistocene locality: Kozi Grzbiet and Miesenheim 1. Late middle and late Pleistocene locality: Weimar Ehringsdorf, Biśnik Cave, Chlupáč Cave and Deszczowa Cave. Postglacial and Holocene locality: Biśnik Cave (uppermost layers), Jasna Strzegowska Cave and Poland in general. Data from Stefaniak (2015) and references therein.

material (Barycka, 2008). The results were confirmed by a few radiocarbon dates, which showed a young age of these remains (Nadachowski, personal commun., 2015). Except few individuals, the specimens were younger than $12 \mathrm{Ka}$, like the specimen from Solna Jama Cave.

\section{Order ARTIODACTYLA Owen, 1848 \\ Family CERVIDAE Goldfuss, 1820 \\ Genus CAPREOLUS Gray, 1821 \\ Capreolus capreolus (Linnaeus, 1758)}

Figure 14

Specimens. Damaged phalanx II (JSJ/Cca/1), damaged phalanx III (JSJ/Cca/2).

Measurements. Phalanx II (JSJ/Cca/1): L, 25.93 $\mathrm{mm}$; pl, $12.84 \mathrm{~mm}$; pB, $9.20 \mathrm{~mm}$; $\mathrm{mB}, 6.94 \mathrm{~mm}$; dL, $10.23 \mathrm{~mm}$; dB, $6.81 \mathrm{~mm}$.

Remarks. The second phalanx was found on the bottom of the main chamber and the third from the lower niche, situated just behind the "Wolverine Niche". The state of preservation indicated that phalanx II was older than phalanx III, which looked quite fresh. In its size and proportions phalanx II from the postglacial/Holocene sediments of Solna Jama Cave is similar to those from other Holocene sites (Figure 14). The specimen is quite long, but narrow, and is within the lower part of variation range of the recent forms. The largest and most massive phalanges are those of the middle Pleisto- cene Ca. capreolus from Kozi Grzbiet (MIS 18-17, classified as $\mathrm{Ca}$. suessenbornensis) and from Miesenheim I (MIS 13, regarded as Ca. priscus). Stratigraphically younger specimens, dated as late middle and late Pleistocene as nearly as large, but not so robust. Postglacial and Holocene individuals varied widely in size, and on average are more gracile (Figure 14). However, the scanty data do not allow a broader discussion, and it can be only cautiously said that, like the other skeletal elements, also phalanges confirmed to the gradual size decrease since the middle Pleistocene till the Holocene (Stefaniak, 2015).

The information on the fossil ungulate fauna from Lower Silesia is very scanty. The remains come from cave and open sites, excavated before and after WWII (Wiśniewski et al. 2009). Capreolus capreolus was mentioned from Radochowska Cave (Złote Mts) by Frenzel $(1936,1937)$ and from Cisowe 1 and 2 Rock Shelter by Zotz (1937a, 1937b, 1939) (Bieroński et al., 2007, 2009b). Bieroński et al. (2007) and Wiśniewski et al. (2009) confirmed its occurrence in two rock shelters on Miłek Hill: Trwoga Paleontologa and Małgorzaty Rock Shelters, dated as Atlantic period. Wiszniowska (1989) mentioned few remains from a corridor called "Korytarz Człowieka Pierwotnego" in Niedźwiedzia Cave near Kletno (Bieroński et al., 2009a). Finally, Rogala et al. (1998) provided a 
brief description of right mandible, found in Pod Torami Cave near Ołdrzychowice Kłodzkie. All these records are dated as postglacial or Holocene age, while in the Sudetes finds of Pleistocene age are unknown. Because of the lack of absolute dates, like C14 AMS or UTh, and the scanty fossil material nothing or very little can be said about the time of re-colonisation of the Sudetes by $\mathrm{Ca}$. capreolus.

Family BOVIDAE Gray, 1821

Genus BISON Hamilton Smith, 1827 or BOS Linnaeus, 1758

Bison/Bos sp.

Specimen. Damaged, left M2 (JSJ.Bx/1).

Remarks. The examined tooth belonged to an adult, in its prime, with its crown worn to the extent suggesting an age between 5 and 7 years. The morphology of molars of both large bovines, the genera Bos and Bison, is very similar. According to Prat (1987), the main difference between them is the presence of a small enamel islet, situated in the central crown part, in the genus Bison (also in Bos taurus Linnaeus, 1758). Contrary to that, Sala (1986) found this structure in the genus Bos, but not in the genus Bison. Moreover, morphometrically the M2 from Solna Jama fits almost exactly within the range of Bos taurus from medieval Polish sites (Chrzanowska, 1975, 1985) and is narrower than M2 of Bison bonasus (Linnaeus, 1758) or Bos primigenius Bojanus, 1827 (Brudnicki et al., 2011). For these reasons the examined specimen was classified only as an undetermined large bovid.

\section{DISCUSSION}

At least 21 mammal species have been found in sediments of Solna Jama Cave. Quite surprisingly, the rodent material is relatively sparse. Soricidae and Chiroptera are represented by two species and rodents by five forms. The single find of Capreolus capreolus and an undetermined, large bovid are the only records of Artiodactyla. Carnivores are the most numerous (10 species) mammal taxon and represent at least four families. Besides the fossil material of mammals some fragments snail shells and undetermined bird fragments were found.

Two radiocarbon dates showed the presence of two main faunal assemblages. The older one, with Ursus ingressus and $U$. arctos priscus, was dated as MIS 3. The age was confirmed by AMS C14 date of $39900 \pm 700$ cal.BP (Poz-27294), taken from $U$. ingressus fibula. The second date
(12430 \pm 60 cal.BP, Poz-35321), taken from phalanx 2 of Gulo gulo, confirmed the postglacial age of the assemblage. The second assemblage, the main fauna, was represented by all the recorded mammal species, excluding the bears. It included species associated with forest (Sciurus vulgaris, Myodes glareolus, Martes martes, Felis silvestris and Capreolus capreolus), open habitats (Cricetus cricetus and Mustela eversmanii) and also euryoecious species (Arvicola terrestris, Canis lupus, Vulpes vulpes, Gulo gulo, Meles meles and Mustela nivalis). Gulo gulo and Mustela eversmanii are regarded as relict, cold-adapted components of the so-called "Pleistocene mammoth steppe fauna." The palaeoecological analysis showed the existence of taiga type forests together with small streams and meadows in the environs of the cave (Bieroński et al., 2007; Stefaniak et al., 2009).

The main fauna (mostly rodents and carnivores) documented the postglacial and Holocene succession of forests, a decrease in the coldadapted fauna and an expansion of forest species. The presence of Gulo gulo and Mustela eversmanii is noteworthy; both mustelids can be regarded as Pleistocene relict species, whose geographical range decreased in the postglacial period, and they retreated to the north (G. gulo) and east (Mu. eversmanii). Apart from Solna Jama Cave, none of the species was found in the Polish postglacial localities. The mosaic habitat in the environs of Solna Jama Cave was not the preferred habitat for $M u$. eversmanii, which naturally occurs in steppe habitats. Fossil and recent data indicate that its distribution often coincided (and still does) with large, steppe rodents like Spermophilus, Cricetus cricetus or Allactaga. However, recent studies show that the species is able to adapt to rapid environmental changes and lived, for example, in intensively used agricultural landscapes, where smaller rodents like Microtus could also play an important role in its diet. Besides few bones of $\mathrm{Cr}$. cricetus, no other large, steppe rodent was found, but Microtus, together with $\mathrm{Cr}$. cricetus, may have been to sustain the steppe polecat in this mosaic habitat.

Ursus arctos was rare in Poland in late middle Pleistocene, and is a constant but not very common member of late Pleistocene faunal assemblages. It is unclear if the form evolved from a local $U$. arctos population or if it migrated into Central Europe from the east. The large, primitive arctoid bear, found in few interglacial sites, mostly of the Eemian period, besides its larger size and stouter build, can be distinguishing from the Holocene and recent specimens based on its dental morphology. 
Overall, it was a very large $U$. arctos with many primitive, speleoid features like more complicated surface of cheek teeth together with their broader crowns and more robust metacarpals/metatarsals. This huge, primitive form became extinct in Europe in the postglacial period and was not closely related to $U$. arctos, which at present occurs in Central Europe.

Gulo gulo is regarded as well adapted to a cold, snowy weather and restricted to three climate zones (Hernández Fernández, 2001). The presence of G. gulo in the fauna from Solna Jama Cave should indicate cold climatic conditions. Additionally, the huge size of this particular individual, together with the dwarf-sized Mustela nivalis, support this hypothesis.

Finally, Solna Jama Cave was situated on one of the few migration corridors crossing the Carpathian arch (Sudety Mts are the western continuation of the Carpathian Mts). The Gołodolnik stream valley created a wide corridor providing a connection between the fauna from the south (now the Czech Republic) and the north (now Poland). Bordered on the left by the Orlicke Hory and on the right by the Śnieżnik massif it served animal migrations in both directions. In the future, more detail excavations are planned, especially in the newly discovered chimney running from the slope of the hill, probably connected with the cave (Stefaniak et al., 2009). It is filled with sediments mixed with animal bones and still a promising site, which requires further excavations.

\section{ACKNOWLEDGEMENTS}

The paper is honored to memory of Jerzy Bieroński, one of the most distinguished researchers of Solna Jama Cave and Sudeten caves, which has devoted most of his scientific work. Authors are very grateful to Prof. B.M. Pokryszko for linguistic improvements and two anonymous reviewers for their critical and helpful comments and suggestions. This research was supported by the Ministry of Science and Higher Education, Poland (project 1076/S/IBŚ/2015). The project was supported also by the grant of National Science Centre, Poland, grant no. 2015/17/D/ST10/01907.

\section{REFERENCES}

Abelentsev, V.I. 1968. Fauna Ukraini. Naukova Dumka, Kiev. (In Ukrainian)

Abramov, A.V. and Baryshnikov, G.F. 2000. Geographic variation and intraspecific taxonomy of weasel Mustela nivalis (Carnivora, Mustelidae). Zoosystematica Rossica, 8:365-402.
Allen, C.M. 1933. The least weasel a circumboreal species. Journal of Mammalogy, 14:316-319.

Anderson, E. 1970. Quaternary evolution of the genus Martes (Carnivora, Mustelidae). Acta Zoologica Fennica, 130:1-132.

Arndt, W. 1921. Beitrag zur Kenntnis der Höhlenfauna. Ergebnis einer faunistischen Untersuchung der Höhlen Schlesiens. Zoologischer Anzeiger, 52(12/ 13):311-316. (In German)

Arndt, W. 1923. Speläobiologische Untersuchungen in Schlesien. Speläologische Jahrbuch, 4:95-114. (In German)

Baca, M., Mackiewicz, P., Stankovic, A., Popović, D., Stefaniak, K., Czarnogórska, K., Nadachowski, A., Gąsiorowski, M., Hercman, H., and Węgleński, P. 2014. Ancient DNA and dating of cave bear remains from Niedźwiedzia Cave suggest early appearance of Ursus ingressus in Sudetes. Quaternary International, 339-340:217-223.

Ballesio, R. 1983. Le gisement Pléistocène supérieur de la grotte de Jaurens à Nespouls, Corrèze, France: les Carnivores (Mammalia, Carnivora). III Ursidae Ursus arctos Linnaeus. Nouvelles Archives du Muséum d'Histoire naturelle de Lyon, 21:9-43. (In French)

Bangs, O. 1896. On a small collection of mammals from Lake Edward, Quebec. Proceedings of The Biological Society of Washington, 10:45-52.

Barycka, E. 2008. Middle and late Pleistocene Felidae and Hyaenidae of Poland. Fauna Poloniae, 2:1-228.

Bieroński, J., Socha, P., and Stefaniak, K. 2007. Deposits and fauna of the Sudetic caves - the state of research. Studies of the Faculty of Earth Sciences University of Silesia, 45:183-201.

Bieroński, J., Stefaniak, K., Hercman, H., Socha, P., and Nadachowski, A. 2009a. Palaeogeographical and palaeoecological studies of sediments of the Niedźwiedzia (Bear) Cave in Kletno. Studies of the Faculty of Earth Sciences University of Silesia, 56:401422.

Bieroński, J., Burdukiewicz, J.M., Socha, P., Stefaniak, K., Hercman, H., and Nadachowski, A. 2009b. Palaeogeographical, archeological and palaeozoological studies in the Radochowska Cave. Studies of the Faculty of Earth Sciences University of Silesia, 56:455-475.

Bojanus, L.H. 1827. De uro nostrate eiusque sceleto commentatio scripsit et bovis primigenii sceleto auxit. Nova Acta Physico-Medica Academiae Caesareae Leopoldino-Carolinae Naturae Curiosorum, 13(2):411-478.

Borkhausen, M.B. 1797. Botanisches Wörterbuch oder Versuch einer Erklärung der vornehmsten Begriffe und Kunstwörter in der Botanik. Georg Friedrich Heyer, Giessen. (In German)

Bowditch, T.E. 1821. An Analysis of the Natural Classifications of Mammalia for the Use of Students and Travellers. J. Smith, Paris. 
Brudnicki, W., Brudnicki, A., Kirkiłło-Stacewicz, K., Grzywacz, K., Nowicki, W., Skoczylas, B., and Wach, J. 2011. The characteristics of the cheel teeth in auroch Bos primigenius Bojanus (1827) from the Tuchola Forest. Electronic Journal of Polish Agricultural Universities, Series Veterinary Medicine, 14(4):1-10.

Buchalczyk, T. 1964. Rząd: Drapieżne - Carnivora, p. 192-229. In Kowalski, K. (ed.), Klucze do oznaczania kręgowców Polski. Część V, Ssaki, Mammalia. Państwowe Wydawnictwo Naukowe, Warszawa Kraków. (In Polish)

Buchalczyk, T. and Ruprecht, A. 1975. Tchórz stepowy, Mustela eversmanii Lesson, 1827 - nowy ssak w faunie Polski. Przegląd Zoologiczny, 19:84-90. (In Polish)

Charles, R. 2000. Prehistoric mustelid exploitation: an overview, p. 127-140. In Griffiths, H.I. (ed.), Mustelids in a Modern World. Management and Conservation Aspects of Small Carnivore: Human Interactions. Backhuys Publishers, Leiden.

Chrzanowska, W. 1975. Fosylne i subfosylne szczątki kostne zwierząt z Jaskini Zamkowej Dolnej w Olsztynie k. Częstochowy. Zeszyty Naukowe Akademii Rolniczej we Wrocławiu. Weterynaria, 32(107):185194. (In Polish)

Chrzanowska, W. 1985. Dzikie ssaki Śląska w pradziejach w świetle kostnych materiałów wykopaliskowych, p. 21-32. In Wyrost, P. (ed.), Dawna fauna Śląska w świetle badań archeologicznych. Ossolineum, Wrocław. (In Polish)

Cyrek, K., Nadachowski, A., Madeyska, T., Bocheński, Z., Tomek, T., Wojtal, P., Miękina, B., Lipecki, G., Garapich, A., Rzebik-Kowalska, B., Stworzewicz, E., Wolsan, M., Godawa, J., Kościów, R., Fostowicz-Frelik, Ł., and Szyndlar, Z. 2000. Excavation in the Deszczowa Cave (Kroczyckie Rocks, Częstochowa Upland, Central Poland). Folia Quaternaria, 71:5-84.

Daszkiewicz, P., Jędrzejewska, B., and Samojlik, T. 2005. Rosomak w Rzeczypospolitej w dawnych źródłach. Przegląd Zoologiczny, 159:167-172. (In Polish)

Diedrich, C.G. 2008. A Late Pleistocene wolverine Gulo gulo (Linné, 1758) skeleton from the Sloup Cave in the Moravian Karst, Czech Republic. Annalen des Naturhistorischen Museums in Wien. Serie A für Mineralogie und Petrographie, Geologie und Paläontologie, Anthropologie und Prähistorie, 110:123-132.

Diedrich, C. 2014. Holotype skulls, stratigraphy, bone taphonomy and excavation history in the Zoolithen Cave and new theory about Esper's "great deluge". $E$ \& G Quaternary Science Journal, 63(1):78-98.

Diedrich, C.G. and Copeland, J.P. 2010. Upper Pleistocene Gulo gulo (Linné, 1758) remains from the Srbsko Chlum-Komin hyena den cave in the Bohemian Karst, Czech Republic, with comparisons to contemporary wolverines. Journal of Cave and Karst Studies, 72 (2):122-127.
Dittrich, G. 1935. Zur Kenntnis schlesischer Tropfsteinhöhlen. Die Salzlöcher. Naturschutz, 16(13):308-309. (In German)

Dittrich, G. 1939. Verzeichnis der Sudetenhöhlen. Mitteilungen über Höhlen und Karstforschung, 1:38-39. (In German)

Döppes, D. 2001. Gulo gulo (Mustelidae, Mammalia) im Jungpleistozän Mitteleuropas. Beiträge zur Paläontologie, 26:1-95. (In German)

Dumnicka, E. 2007. Specyficzność fauny wód podziemnych Sudetów, p. 43. In Stefaniak, K., Szelerewicz, M., and Urban, J. (eds.), Materiały 41 Sympozjum Speleologicznego. Sekcja Speleologiczna Polskiego Towarzystwa Przyrodników im. Kopernika, Kraków. (In Polish)

Ehrenberg, K. 1929. Über einen bemerkenswerten Bärenschädel a. d. Bärenhöhle bei Winden im Burgenland. Sitzungsberichte und Anzeiger der Österreichische Akademie der Wissenschaften, Mathematisch-Naturwissenschaftliche Klasse Abteilung 1, Biologische Wissenschaften und Erdwissenschaften, 12:14-39. (In German)

Erxleben, J.C. 1777. Systema regni animalis per classis, ordines, genera, species, varietates, cum synonymia et historia animalium. Classis I, Mammalia. Impensis Weygandiansis, Leipzig. (In Latin)

Fischer von Waldheim, G. 1817. Adversaria zoologica. Mémoires de la Société Impériale Des Naturalistes Moscou, 5:357-472. (In Latin)

Frenzel, J. 1936. Knochenfunde in der Reyersdorfer Tropsteinhöhle. Beiträge zur Biologie des Glatzer Schneeberges, 2:121-134. (In German)

Frenzel, J. 1937. Die Apterygotenfauna des Glatzer Schneeberges. Beiträge zur Biologie des Glatzer Schneeberges, 3:249-321. (In German)

Frisch, J.L. 1775. Das Natur-System der vierfüßigen Thiere in Tabellen, darinnen alle Ordnungen, Geschlechte und Arten, nicht nur mit bestimmenden Benennungen, sondern beygesetzten unterscheidenden Kennzeichen angezeigt werden zum Nutzen der erwachsenen Schuljugend. Günther, Glogau. (In German)

Furmankiewicz, J. and Furmankiewicz, M. 2002. Bats hibernating in the natural caves in the Polish part of the Sudetes. Przyroda Sudetów Zachodnich, Suplement, 2:15-38. (In Polish)

Gardner, C.L., Ballard, W.B., and Jessup, H. 1986. Long distance movement by an adult wolverine. Journal of Mammalogy, 67:603.

Gloger, C.L. 1833. Schlesiens Wirbeltierfauna. Verlag A. Schulz \& Co., Breslau. (In German)

Głowaciński, Z. and Profus, P. 1987. Jeszcze jedno stwierdzenie tchórza stepowego Mustela eversmanii Lesson, 1827 w Polsce. Przegląd Zoologiczny, 31(4):523-526. (In Polish)

Goldfuss, A. 1818a. Descriptio cranii ex ursorum genere memorabilis, nuperrime in cavernis prope Muggendorf reperti. Nova Acta Physico-Medica Academiae 
Caesarae Leopoldino-Carolinae Naturae Curiosorum, 10(2):259-276. (In Latin)

Goldfuss, A. 1818b. Bescreibung eines fossilen Vielfrass-Schädels aus der Gailenreuther Höhle. Nova Acta Physico-Medica Academiae Caesarae Leopoldino-Carolinae Naturae Curiosorum, 9:313-322. (In German)

Goldfuss, A. 1820. Handbuch der Zoologie. Johann Leonard Schrag, Nurnberg. (In German)

Goldfuss, A. 1823. Osteologische Beiträge zur Kenntnis verschiedener Säugethiere der Vorwelt. Nova Acta Physico-Medica Academiae Caesarae LeopoldinoCarolinae Naturae Curiosorum, 11(2):451-490. (In German)

Gray, J.E. 1821. On the natural arrangement of vertebrose animals. London Medical Repository, 15:269310.

Güldenstaedt, J.A. 1770. Reisen durch Russland und im Caucasischen Gebürge. Kaiserische Akademie der Wissenschaften, Sankt Petersburg. (In German)

Haglund, B. 1966. Winter habits of the lynx (Lynx lynx L.) and wolverine (Gulo gulo L.) as revealed by tracking in the snow. Viltrevy, 4:81-310.

Hamilton Smith, C. 1827. The class Mammalia. Supplement to the order Ruminantia, p. 414-418. In Griffith, E., Hamilton-Smith, C., and Pidgeon, E. (eds.), The Animal Kingdom, Arranged in Conformity with its Organization, by the Baron Cuvier, with Additional Descriptions of all the Species Hitherto Named, and of Many Not Before Noticed, Volume IV. G. B. Whittaker, London.

Heptner, V.G. and Naumov, N.P. 1967. Mlekopitayushchije Sovetskogo Soyuza. Volume II, Part Ib. Żinszczinyje (Kunicy; dopolnitelnych widow). Vysshaya Shkola Publishers, Moscow. (In Russian)

Hernández Fernández, M. 2001. Análisis paleoecológico y paleoclimático de las sucesiones de mamíferos del Plio-Pleistoceno ibérico. PhD Thesis. Universidad Complutense de Madrid, Madrid, Spain. (In Spanish)

Hilpert, B. 2006. Die Ursiden aus Hunas - Revision und Neubearbeitung der Bärenfunde aus der SteinbergHöhlenruine bei Hunas (Gde. Pommelsbrunn, Mittelfranken, Bayern). PhD Thesis. Naturwissenschaftlichen Fakultäten der Universität Erlangen-Nürnberg, Erlangen, Germany. (In German)

Hornocker, M.G. and Hash, H.S. 1981. Ecology of the wolverine in north-western Montana. Canadian Journal of Zoology, 59:1286-1301.

Hoyer, H. 1937. Fauna dyluwialna Polski. Kosmos, 62:181-210. (In Polish)

Huguney, M. 1975. Les Mustélidés (Mammalia, Carnivora) du gisement pléistocène moyen de la Fage (Corrèze). Nouvelles Archives du Muséum d'Histoire naturelle de Lyon, 13:29-46. (In French)

Jánossy, D. 1955. Die Vögel- und Säugetierreste der spätpleistozänen Schichten der Höhle von Istallöskö. Acta Archaeologica Academiae Scientiarum Hungaricae, 5:149-181. (In German)
Jędrzejewska, B. and Jędrzejewski, W. 2001. Ekologia zwierząt drapieżnych Puszczy Białowieskiej. Polskie Wydawnictwa Naukowe, Warszawa. (In Polish)

King, C.M. 1989. The advantages and disadvantages of small size to weasels, Mustela species, p. 302-334. In Gittleman, J. (ed.), Carnivore Behavior, Ecology \& Evolution. Cornell University Press, London.

King, C.M. and Powell, R.A. 2007. The Natural History of Weasels and Stoats. Ecology, Behavior, and Management. Oxford University Press, New York.

Kormos, T. 1911. Die Pleistozäne Säugetierfauna der Felsnische Puspakoros bei Hamor. Mitteilungen aus dem Jahrbuche der Königlichen Ungarischen Geologischen Reichsanstalt, 19:125-147. (In German)

Kormos, T. 1934. Neue und wenig bekannte Musteliden aus dem ungarischen Oberpliozän. Folia Zoologica et Hydrobiologica, 5(2):129-157. (In German)

Kostroň, K. 1948. Tchoř stepni čili Eversmanni v (Putorius eversmanii Lesson 1827), nový a značně rozšiŕeny člen zviřeny Československa. Práce Moravskoslezsko akademie věd prírodních, 20:1-98. (In Czech)

Kowalski, K. 1954. Jaskinie Polski. T. 3. Państwowe Wydawnictwo Naukowe, Warszawa. (In Polish)

Kowalski, K. 1959. Katalog ssaków plejstocenu Polski. Państwowe Wydawnictwo Naukowe, Warszawa, Wrocław. (In Polish)

Kowalski, K. 2001. Pleistocene rodents of Europe. Folia Quaternaria, 72:3-389.

Krajcarz, M.T. 2012. Small fossil wolverine Gulo from Middle Pleistocene of Poland. Acta Zoologica Cracoviensia, 55(1):79-87.

Krajcarz, M.T., Bosák, P., Šlechta, S., Pruner, P., Komar, M., Dresler, J., and Madeyska, T. 2014a. Sediments of Biśnik Cave (Poland): Lithology and stratigraphy of the Middle Palaeolithic site. Quaternary International, 326-327:6-19.

Krajcarz, M.T., Krajcarz, M., Goslar, T., and Nadachowski, A. 2014b. The first radiocarbon dated steppe polecat (Mustela eversmanii) from the Pleistocene of Poland. Quaternary International, 357:237244.

Krajcarz, M.T., Krajcarz, M., and Marciszak, A. 2014c. Paleoecology of bears from MIS 8 - MIS 3 deposits of Biśnik Cave based on stable isotopes (?13C, ?180) and dental cementum analysis. Quaternary International, 326-327:114-124.

Krajcarz, M.T. and Madeyska, T. 2010. Application of the weathering parameters of bones to stratigraphical interpretation of the sediments from two caves (Deszczowa Cave and Nietoperzowa Cave, KrakówCzęstochowa Upland, Poland). Studia Quaternaria, 27:43-54.

Krakhmalnaya, T.V. 1999. Carnivore remains from Late Pleistocene and Holocene deposits in the Ukraine. Archäologie in Eurasien, 6:223-235.

Krukowski, S. 1939. Paleolit. Encyklopedia Polska. Prehistoria Ziem Polskich, 4(1):1-117. (In Polish) 
Kuhl, H. 1819. Die deutschen Fledermäuse. Wetterausche Annalen der Gesellschaft für Naturkunde von Hanau, 1(2):185-215. (In German)

Kuntze, R. 1928. Obecny stan wiedzy o stanie ssaków i ptaków wschodniego Podola. Kosmos, 53:683-698. (In Polish)

Kurtén, B. 1959. On the bears of the Holsteinian Interglacial. Stockholm Contributions in Geology, 2:73-102.

Kurtén, B. 1965a. The Carnivora of the Palestine caves. Acta Zoologica Fennica, 107:1-74.

Kurtén, B. 1965b. On the evolution of the European wild cat, Felis silvestris Schreber. Acta Zoologica Fennica, 111:1-34.

Kurtén, B. 1968. Pleistocene Mammals of Europe. Weidenfeld and Nicolson, London.

Lanszki, J. and Heltai, M. 2007. Diet of the European polecat and the steppe polecat in Hungary. Mammalian Biology (Zeitschrift für Säugetierkunde), 72(1):49-53.

Lesson, R.-P. 1827. Manuel de mammalogie, ou histoire naturelle des mammifères. Roret, Paris. (In French)

Li, S., Yin, B., Dai, X., Yang, F., Yang, S., Wei, W., Fan, N., and Zhou, W. 2012. Prey selection and hunting behaviours of steppe polecat Mustela eversmanni in laboratory studies. Journal of Animal and Veterinary Advances, 11(1):1-8.

Lichtenstein, M.C.H. 1823. Verzeichniss der Doubletten des zoologischen Museums der Känigl. Universität zu Berlin nebst Beschreibung vieler bisher unbekannter Arten von Säugethieren, Vögelm, Amphibien und fischen. T. Trautweinm, Berlin. (In German)

Link, H.F. 1795. Beyträge zur Naturgeschichte. Ueber die Lebenskräfte in naturhistorischer. Rücksicht und die Classification der Säugethiere. K.C. Stiller, Rostok and Leipzig. (In German)

Linnaeus, C. 1758. Systema naturæ per regna tria naturæ, secundum classes, ordines, genera, species, cum characteribus, differentiis, synonymis, locis. Tomus I. Editio decima, reformata. Salvius Impensis Direct, Holmiæ. (In Latin)

Linnaeus, C. 1766. Systema naturæ per regna tria naturæ, secundum classes, ordines, genera, species, cum characteribus, differentiis, synonymis, locis. Tomus I. Editio duodecima, reformata. Salvius Impensis Direct, Holmiæ. (In Latin)

Lichtenstein, H. 1823. Darstellung neuer oder wenig bekannter Säugethiere in Abbildungen und Beschreibungen: von fünf und sechzig Arten auf funfzig colorirten Steindrucktafeln nach den Originalen des Zoologischen Museums der Universität zu Berlin. C. G. Lüderitz, Berlin. (In German)

Loth, E. 1933. Rosomak (Gulo borealis Nilss.) w Gródku II na Wołyniu. Sprawozdania Towarzystwa Nauk Warszawa, 7-9:137-146. (In Polish)

Lubicz-Niezabitowski, E.L. 1934. Bericht über die Säugetiere Polens und ihre geographische Verbreitung. Zeitschrift für Säugetierkunde, 9:188-197. (In German)
Lüps, P. and Wandeler, A. 1993. Meles meles - Dachs, p. 856-907. In Niethammer, J. and Krapp, F. (eds.), Handbuch der Säugetiere Europas. Band 5: Raubsäuger - Carnivora (Fissipedia). Teil II: Mustelidae 2, Viverridae, Herpestidae, Felidae. AULA-Verlag, Wiesbaden. (In German)

Mallye, J.B. 2007. Les restes de blaireau en contexte archeologique: taphonomie, archeozoologie et éléments de discussion des séquences préhistoriques. $\mathrm{PhD}$ Thesis, University of Bordeaux, Bordeaux, France. (In French)

Marciszak, A. 2012. Mustelids (Mustelidae, Carnivora, Mammalia) from the Pleistocene of Poland. Unpublished PhD thesis, Department of Paleozoology, University of Wrocław, Poland. (In Polish)

Marciszak, A. 2014. Presence of Panthera gombaszoegensis (Kretzoi, 1938) in the late Middle Pleistocene of Biśnik Cave, Poland, with an overview of Eurasian jaguar size variability. Quaternary International, 326327:105-113.

Marciszak, A. and Socha, P. 2014. Stoat Mustela erminea Linnaeus, 1758 and weasel Mustela nivalis Linnaeus, 1766 in palaeoecological analysis: A case study of Biśnik Cave. Quaternary International, 339340:258-265.

Marciszak, A., Socha, P., Nadachowski, A., and Stefaniak, K. 2011. Carnivores from Biśnik Cave. Quaternaire, Hors-série, 4:101-106.

Mostecký, V. 1963. Der pleistozäne Bär Ursus taubachensis Rode aus der Schlucht „Chlupáčova sluj“ bei Koněprusy. Sborník Národního Muzea, 19B(2):75-101. (In German)

Musil, R. 1964. Die Braunbären aus dem Ende des lezten Glazials. Časopis Moravského Musea, Vědy přirodni, 49:83-102. (In German)

Musil, R. 1996. Čertova pec a jeji fauna. Slovenský kras, 34:5-56. (In Slovak)

Muzolf, B., Stefaniak, K., Tomek, T., Wertz, K., Socha, P., Cyrek, K., Mirosław-Grabowska, J., Madeyska, T., and Nadachowski, A. 2009. Multiculturate sites on Mt. Birów in Podzamcze. Studies of the Faculty of Earth Sciences University of Silesia, 56:85-144.

Nadachowski, A., Stefaniak, K., Szynkiewicz, A., Marciszak, A., Socha, P., Schick, P., and August, P. 2011. Biostratigraphic importance of the Early Pleistocene fauna from Żabia Cave (Poland) in Central Europe. Quaternary International, 248:204-218.

Ossowski, G. 1885. Jaskinie okolic Ojcowa pod względem paleo-etnologicznym. Pamiętnik Akademii Umiejętności, Wydział Matematyczno-Przyrodniczy, 11:1-60. (In Polish)

Otto, A. 1923. Glatzer Wanderbuch. Glatzer Heimatbücher, 7:1-295. (In German)

Owen, R. 1848. Description of teeth and portions of jaws of two extinct Anthracotherioid quadrupeds (Hyopotamus vectianus and Hyop. bovinus) discovered by the Marchioness of Hastings in the Eocene deposits on the NW coast of the Isle of Wight: with an attempt to develope Cuvier's idea of the Classification of 
Pachyderms by the number of their toes. Quarterly Journal of the Geological Society of London, 4:103141.

Pacher, M. 2007. The type specimen of Ursus priscus Goldfuss, 1810 and the uncertain status of Late Pleistocene brown bears. Neues Jahrbuch für Geologie und Paläontologie, Abhandlungen, 245:331-339.

Pallas, P.S. 1780. Spicilegia zoologica: quibus novae imprimis et obscurae animalium species iconibus, descriptionibus atque commentariis illustrantur. Gottlieb August Lange, Berolini. (In Latin)

Pasitschniak-Arts, M. and Lariviére, S. 1995. Gulo gulo. Mammalian Species, 499:1-10.

Pateff, P. 1926. Süsswasser-Rhizopoden aus der Höhle Salzlöcher (Schlesien). Mitteilungen der Höhlen und Karstforschung, 2:46-49. (In German)

Pax, F. 1921. Die Tierwelt Schlesiens. G. Fischer Verlag, Jena. (In German)

Pax, F. 1925. Wirbeltierfauna von Schlesien. Faunistische und Tiergeograpische Untersuchungen im Obergebeit. Verlag von Gebrüder Borntraeger, Berlin. (In German)

Peters, G., Heinrich, W.-D., Beurton, P., and Jäger, K.-D. 1973. Fossile und rezente Dachsbauten mit massenanreicherungen von Wirbeltierknochen. Mitteilungen aus dem Zoologischen Museum Berlin, 48:415435. (In German)

Petronio, C., Canzio, d.E., and Stefano, G.d. 2003. Morphological and biometrical differences in the limb bones of Ursus arctos and Ursus spelaeus and phylogenetical considerations on the two species. Palaeontographica, Abetilung A, 269(4-6):137-152.

Pinel, P. 1792. Recherches sur une nouvelle méthode de classification des quadrupèdes, fondée sur la structure mécanique des parties osseuses qui servent à l'articulation de la mâchoire inférieure. Actes de la société d'histoire naturelle de Paris, 1:50-60. (In French)

Pomel, M. 1853. Catalogue méthodique et desriptif des vertébrés fossils découvertes dans le basin hydrographique supérieur de la Loire er surtout dans la vallée de son affluent principal l'Allier. J-B. Baillière, Paris. (In French)

Pomorski, R.J. 1990. Onychiurus paxi Stach, 1939, a junior synonym of Onychiurus (Onychiurus) denisi, Stach, 1934 (Collembola). Polskie Pismo Entomologiczne, 60:59-63.

Pomorski, R.J. 1992. Collembola of caves and some adits of the Polish Sudetes. Acta Universitatis Wratislaviensis, 1539(25):27-44.

Prat, F. 1987. Podstawy oznaczania szczątków ważniejszych ssaków plejstoceńskich. Skrypty Uczelniane. Uniwersytet Jagielloński, Kraków. (In Polish)

Pulina, M. 1996. Jaskinie Sudetów. Polskie Towarzystwo Przyjaciół Nauk o Ziemi, Warszawa. (In Polish)

Pulliainen, E. 1993. Gulo gulo (Linnaeus, 1758) - Vielfrass, p. 481-520. Niethammer, J. and Krapp, F. (eds.), Handbuch der Säugetiere Europas. Band 5: Raubsäuger - Carnivora (Fissipedia). Teil II: Musteli- dae 2, Viverridae, Herpestidae, Felidae. AULA-Verlag, Wiesbaden. (In German)

Pusch, G.G. 1837. Polens Paläontologie oder Abbildung und Beschreibung der vorzüglichsten und der noch unbeschriebenen Petrefakten aus den Gebirgsformationen in Polen, Volhynien und den Karpathen nebst einigen allgemeinen Beiträgen zur Petrefaktenkunde und einem Versuch zur Vervollständigung der Geschechte des europäischen Auer-Ochsen. E. Schweizerbart's Verlagshandlung, Stuttgart. (In German)

Rabeder, G. 1999. Die Evolution des Höhlenbärengebisses. Mitteilungen der Kommission für Quartärforschung der Österreichischen Akademie der Wissenschaften, 11:1-102. (In German)

Rabeder, G., Hofreiter, M., Nagel, D., and Withalm, G. 2004. New Taxa of Alpine Cave Bears (Ursidae, Carnivora). Cahiers Scientifiques, Hors série, 2:49-67.

Rabeder, G., Pacher, M., and Withalm, G. 2009. Early Pleistocene bear remains from Deutsch-Altenburg (Lower Austria). Mitteilungen der Kommission für Quartärforschung der Österreichischen Akademie der Wissenschaften, 17:1-177. (In German)

Reichstein, H. 1993a. Mustela erminea - Hermelin, p. 533-571. In Niethammer, J. and Krapp, F. (eds.), Handbuch der Säugetiere Europas. Band 5: Raubsäuger - Carnivora (Fissipedia). Teil II: Mustelidae 2, Viverridae, Herpestidae, Felidae. AULA-Verlag, Wiesbaden. (In German)

Reichstein, H. 1993b. Mustela nivalis - Mauswiesel, p. 571-627. In Niethammer, J. and Krapp, F. (eds.), Handbuch der Säugetiere Europas. Band 5: Raubsäuger - Carnivora (Fissipedia). Teil II: Mustelidae 2, Viverridae, Herpestidae, Felidae. AULA-Verlag, Wiesbaden. (In German)

Rogala, W., Placek, W., and Wojtoń, A. 1998. Nowe dane o krasie podziemnym Krowiarek (Sudety Wschodnie). Acta Universitatis Wratislaviensis 2061, Prace Instytutu Geograficznego Seria A, Geografia Fizyczna, 9:13-22. (In Polish)

Römer, F. 1883. Die Knochenhöhlen von Ojców in Polen. Paleontographica, 29:1-41. (In German)

Ruprecht, L. 1985. Dalsze możliwe stanowiska tchórza stepowego, Mustela eversmanii Lesson, 1827 w Polsce. Przegląd Zoologiczny, 29:103-105. (In Polish)

Sabol, M. 1999. The fossil bears from the Okno cave (Demänová valley, Slovakia). Mineralia Slovaca, 31:87-108.

Sabol, M. 2001a. Fossil and subfossil findings of brown bears from selected localities in Slovakia. Slovak Geological Magazine, 7:3-17.

Sabol, M. 2001b. Fossil brown bears of Slovakia. Cadernos Laboratorium Xeolóxico de Laxe, 26:311-316.

Sala, B. 1986. Bison schoetensacki Freud. from Isernia la Pineta (early Mid-Pleistocene, Italy) and revision of the European species of bison. Paleontographica Italica, 74:113-170.

Šálek, M., Spassov, N., Anděra, M., Enzinger, K., Ottlecz, B., and Hegyeli, Z. 2013. Population status, 
habitat associations, and distribution of the steppe polecat Mustela eversmanii in Europe. Acta Theriologica, 58:233-244.

Schellenberg, A. 1932. Deutsche subterrane Amphipoden. Zoologischen Anzeiger, 99:311-323. (In German)

Schellenberg, A. 1935. Höhlenamphipoden des Glatzer Schneeberges. Die Höhlenfauna des Glatzer Schneeberges. Beiträge zur Biologie des Glatzer Schneeberges, 1:72-75. (In German)

Schmid, E. 1940. Variationstatistische Untersuchungen am Gebiss pleistozäner und rezenter Leoparden und anderer Feliden. Zeitschrift für Säugetierekunde, 15:1-179. (In German)

Scholtz, H. 1843. Excursion über Schnallenstein nach der Höhle Salzecke. Übersicht der Arbeiten und Veränderungen der Schlesische Gesellschaft für Vaterlandlicher Kultur im Jahr 1843, 1843:153-154. (In German)

Schreber, J.C.D. 1777. Die Säugthiere in Abbildungen nach der Natur mit Beschreibungen 1776-1778. Wolfgang Walther, Erlangen. (In German)

Schreber, J.C.D. 1780. Die Säugethiere in Abbildungen nach der Natur mit Beschreibungen, Volumen 4. Wolfgang Walther, Erlangen. (In German)

Seidel, J. 1927. Zur Kenntnis schlesischer Fledermäuse. Abhandlungen der Naturforschung Gesellschaft, 30(1):1-39. (In German)

Sickenberg, O. 1968. Der Steppeniltis (Mustela [Putorius] eversmanii soergeli Ehik) in der Niederterrasse der Leine und seine klimageschichtliche Bedeutung. Eiszeitalter Gegenwart, 19:147-163. (In German)

Skalski, A.W. 1984. Fauna wód podziemnych Polski. Przegląd Zoologiczny, 37(1-2):35-50. (In Polish)

Skalski, A.W. 1994. Fauna wód podziemnych Polski. Przegląd Zoologiczny, 38:35-50. (In Polish)

Skarżyński, D. 2001. Notes on morphology of the reproductive stage of two species of the genus Schaefferia Absolon, 1900 (Collembola: Hypogastruridae). Genus, 12:1-5.

Sommer, R. and Benecke, N. 2004. Late- and post-glacial history of the Mustelidae in Europe. Mammal Review, 34:249-284.

Sommer, R. and Benecke, N. 2005. Late-Pleistocene and early Holocene history of the canid fauna of Europe (Canidae). Mammalian Biology (Zeitschrift für Säugetierkunde), 70(4):227-241.

Stach, J. 1939. Die Collembolenfauna der Salzlöcher bei Seitendorf. Beiträge zur Biologie des Glatzer Schneeberges, 5:395-415. (In German)

Stach, J. 1945. The species of the genus Arrhopalites occurring in European caves. Prace Muzeum Przyrodniczego, 1(47):8.

Stach, J. 1947. Onychiurus schoetti (Lie Petersen), a relict from the cave Radochów (Silesia) and its relation to the group of Onychiurus groenlandicus (Tullb) and related species. Prace Muzeum Przyrodniczego, 7:120.
Stach, J. 1949a. The Apterygotan Fauna of Poland II. Families: Neogastruridae and Brachystomellidae. Acta Monographica Musei Historiae Naturalis, Warszawa.

Stach, J. 1949b. The Apterygotan Fauna of Poland III. Families: Anuridae and Pseudachoruitidae. Acta Monographica Musei Historiae Naturalis, Warszawa.

Stammer, H.J. 1936. Die Wasserfauna der Reyersdorferhöhlen. Beiträge zur Biologie des Glatzer Schneeberges, 3:199-214. (In German)

Stefaniak, K. 2015. Neogene and Quaternary Cervidae from Poland. Polish Academy of Sciences, Kraków.

Stefaniak, K. and Bieroński, J. 2009. Caves and rock shelters of the Eastern Sudetes - catalogue of important speleological features. Studies of the Faculty of Earth Sciences University of Silesia, 56:515534.

Stefaniak, K., Bieroński, J., Socha, P., Hercman, H., and Nadachowski, A. 2009. Solna Jama Cave - state of knowledge and research perspectives. Studies of the Faculty of Earth Sciences University of Silesia, 56:491-496.

Szafrańska, P.A., Zub, K., and Konarzewski, M. 2006. Być albo nie być...małym. Kosmos, 270:75-82. (In Polish).

Thenius, E. 1956. Zur Kenntnis der fossilen Braunbären (Ursidae, Mammalia). Sitzungsberichte der Österreichische Akademie der Wissenschaften. Mathematisch Naturwissenschaftliche Klasse, Abteilung 1: Biologie, Mineralogie, Erdkunde und Verwandte Wissenschaften, 165:153-172. (In German)

Tomiałojć, L. 2003. Fakty i mity dotyczące występowania paru gatunków zwierząt w Puszczy Białowieskiej. Przegląd Zoologiczny, 158:137-147. (In Polish)

van den Brink, F.H. 1957. Die Säugetiere Europas. Verlag Paul Parey, Hamburg-Berlin. (In German)

von den Driesch, A. 1976. A guide to the measurement of animal bones from archaeological sites. Bulletin of the Peabody Museum of Archaeology and Ethnology, 1:1-136.

Wilczyński, J., Miękinia, B., Lipecki, G., Lougas, L., Marciszak, A., Rzebik-Kowalska, B., Stworzewicz, E., Szyndlar, Z., and Wertz, K. 2012. Faunal remains from Borsuka Cave - an example of local climate variability during Late Pleistocene in southern Poland. Acta Zoologica Cracoviensia, 55(2):131-155.

Wiszniowska. T. 1980. Nowe stanowisko Meles meles L. (Mustelidae) w plejstocenie Polski. Przegląd Zoologiczny, 24:503-507. (In Polish)

Wiszniowska, T. 1989. Kopalne szczątki zwierzęce, p. 255-279. In Jahn, A., Kozłowski, S., and Wiszniowska, T. (eds.), Jaskinia Niedźwiedzia w Kletnie. Badania $i$ udostępnianie. Ossolineum, Wrocław, Warszawa. (In Polish)

Wiśniewski, A., Stefaniak, K., Wojtal, P., Zych, J., Nadachowski, A., Musil, R., Badura, J., and Przybylski, B. 2009. Archaeofauna or palaeontological record? Remarks on Pleistocene fauna from Silesia. Sprawozdania Archeologiczne, 61:1-62. 
Wojtal, P. 2007. Zooarchaeological Studies of the Late Pleistocene Sites in Poland. Institute of Systematics and Evolution of Animals, Polish Academy of Sciences, Cracov.

Wojtal, P., Wilczyński, J., Nadachowski, A., and Münzel, S.C. 2015. Gravettian hunting and exploitation of bears in Central Europe. Quaternary International, 359-360:58-71.

Wolsan, M. 1989. Drapieżne-Carnivora. Folia Quaternaria, 59-60:177-196. (In Polish)

Wolsan, M. 1993. Mustela eversmanii - Steppeniltis, p. 770-816. In Niethammer, J. and Krapp, F. (eds.), Handbuch der Säugetiere Europas. Band 5: Raubsäuger - Carnivora (Fissipedia). Teil II: Mustelidae 2, Viverridae, Herpestidae, Felidae. AULA-Verlag, Wiesbaden. (In German)

Wołoszyn, B.W. 1968. Badania nietoperzy Dolnego Śląska. Przegląd Zoologiczny, 12:208-220. (In Polish)

Wołoszyn, B.W. 1971. Nietoperze jaskiń Sudetów, p. 129-135. In Skalski, A.W. (ed.), Materiały z III i IV Sympozjum Speleologicznego. Muzeum Okręgowe Częstochowa, Częstochowa. (In Polish)
Wójcik, M. 1974. Szczątki Mustelidae (Carnivora, Mammalia) z późnoplejstoceńskich osadów jaskiń Polski. Acta Zoologica Cracoviensia, 19:75-90. (In Polish)

Wrześniowski, A. 1888. O trzech kiełżach podziemnych. Pamiętnik Fizjograficzny, 8:221-230. (In Polish)

Wyrost, P. 1994. Dawna fauna Polski w świetle badań kostnych materiałów archeologicznych. Roczniki Akademii Rolniczej w Poznaniu, 259 (19):155-176. (In Polish)

Zawisza, J. 1882. Ostatnie poszukiwania w Jaskini Mamuta. Wiadomości Archeologiczne, 4:167-175. (In Polish)

Zimmermann, F.A. 1789. Beyträge zur Beschreibung von Schlesien, Grafschaft Glatz, 9:1-384. (In German)

Zotz, L.F. 1937a. Die schlesischen Höhlen und ihre eiszeitlichen Bewöhner. Wilhelm Gottlieb Korn Verlag, Breslau. (In German)

Zotz, L.F. 1937b. Altsteinzeitlicher Bärenkult in den Sudeten. Altschlesische Blätter, 1-2:4-7. (In German)

Zotz, L.F. 1939. Die Altsteinzeit in Niederschlesien. Kabitsch Verlag, Leipzig. (In German) 


\section{APPENDIX 1.}

Measurements of the canid mandible. 1, total length (infradentale to condyle); 2 , length of infradentale to angular process; $\mathbf{3}$, length of infradentale to angular indentation; $\mathbf{4}$, behind $\mathrm{c} 1$ to condyle length; $\mathbf{5}$, infradentale to anterior margin of masseter fossa; $\mathbf{6}$, posterior margin of $\mathrm{c} 1$ to posterior margin of $\mathrm{m} 3 ; \mathbf{7}$, length of cheek tooth row (anterior margin of $\mathrm{p} 1$ to posterior margin of $\mathrm{m} 3$ ); 8, length of premolar row (anterior margin of $\mathrm{p} 1$ to posterior margin of $\mathrm{p} 4$ ); $\mathbf{9}$, length of molar row (anterior margin of $\mathrm{m} 1$ to posterior margin of $\mathrm{m} 3$ ); 10, distance between mental foramina; 11 , symphysis maximum diameter; 12 , symphysis minimum diameter; 13 , posterior margin of $\mathrm{m} 3$ to condyle length; 14 , condyle height; 15 , condyle breadth; 16, angular process to coronoid process height; 17, mandible maximum height; 18, mandible body height between $\mathrm{p} 2$ and p3; 19, mandible body thickness between $\mathrm{p} 2$ and $\mathrm{p} 3 ; 20$, mandible body height between $\mathrm{m} 1$ and $\mathrm{m} 2$; and 21, mandible body thickness between $\mathrm{m} 1$ and $\mathrm{m} 2$.
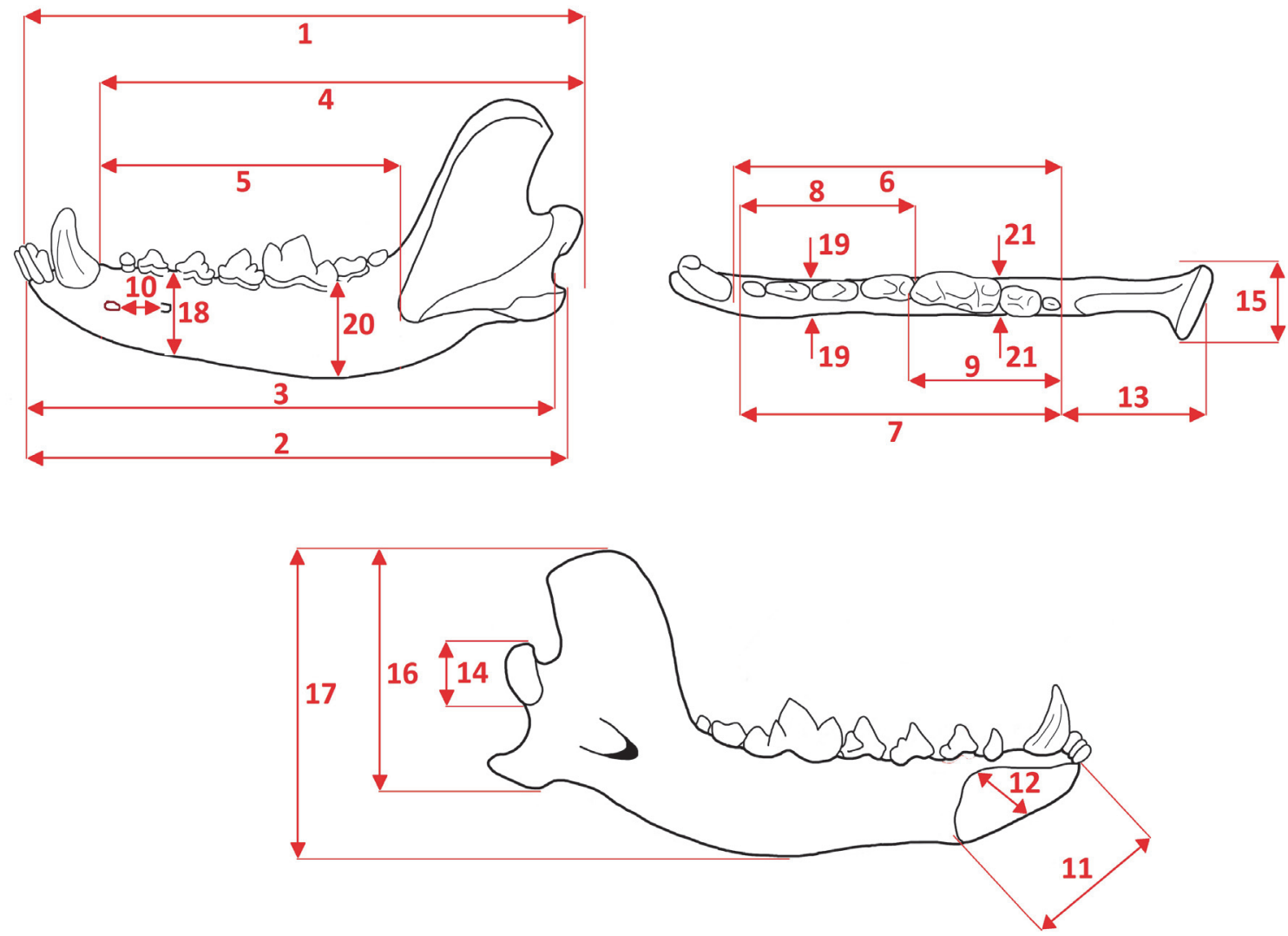


\section{APPENDIX 2.}

Measurements (left) and cusp terminology (right) of the ursid lower second molar (m2). 1, total length; 2, trigonid length from lingual side; $\mathbf{3}$, trigonid length from buccal side; 4 , talonid length from lingual side; $\mathbf{5}$, talonid length from buccal side; $\mathbf{6}$, trigonid breadth; and $\mathbf{7}$, talonid breadth.
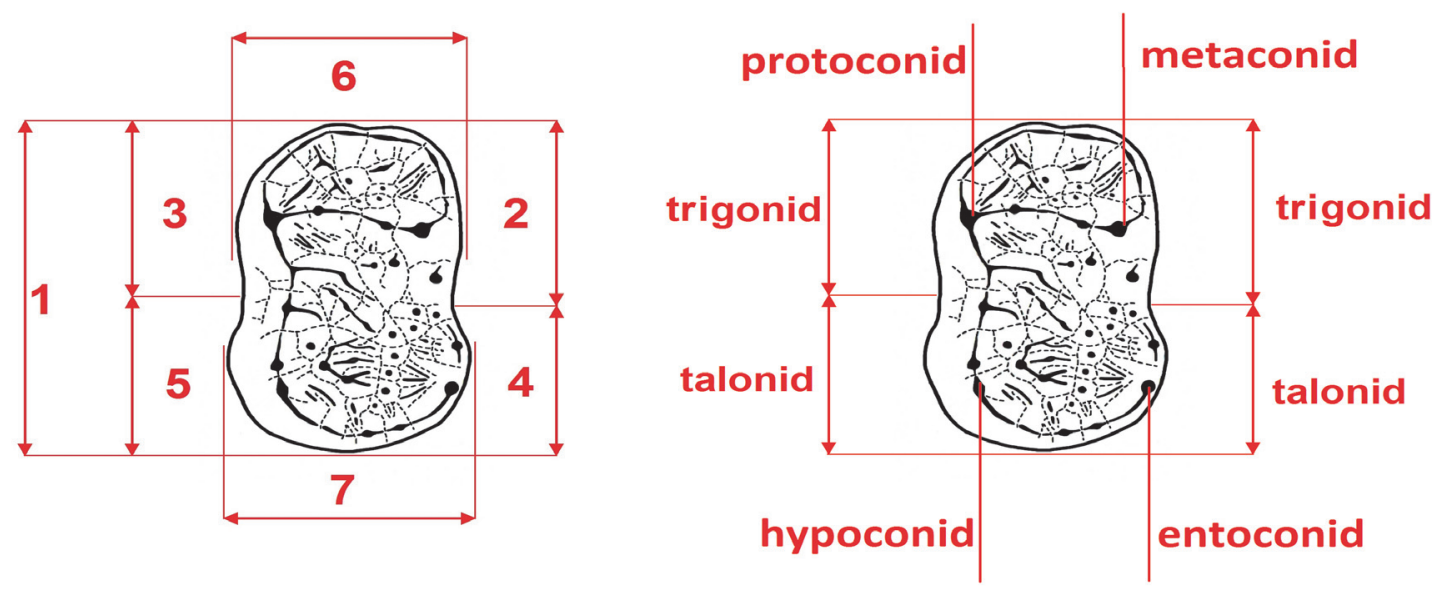


\section{APPENDIX 3.}

Measurements of the mustelid cranium. 1, total length (prosthion-acrocranion); 2, condylobasal length (prostion-occipital condyles); $\mathbf{3}$, basal length (prosthion-basion); $\mathbf{4}$, viscerocranium length (prosthion-point F); $\mathbf{5}$, neurocranium length (point F-acrocranion); 6, facial length (prosthionpoint $F$ ); 7, rostrum length (prosthion-infraorbital); 8, rostrum length (anterior margin of $I 1$ to posterior margin of M1); 9, palatal length (prosthion-staphylion); 10, C1-M1 length on alveoles (anterior margin of alveole of $\mathrm{C} 1$ to the posterior margin of alveole of M1); 11, upper premolars row length on alveoles (anterior margin of alveole of $\mathrm{P} 2$ to the posterior margin of alveole of P4); 12, breadth at zygomatic arches (zygion-zygion); 13, incisors row breadth (13-13 breadth); 14, maximal breadth at the canine alveoli; 15 , maximal breadth at the $\mathrm{P} 4$ alveoli; 16 , maximal breadth at the M1 alveoli; 17 , least palatal breadth; 18, least breadth between infraorbital foramens; 19, least breadth between orbits (entorbital-entorbital); 20, frontal breadth (ectorbitalectorbital); 21, postorbital least breadth (postorbital bar); 22, maximal neurocranium breadth (euryon-euryon); 23, mastoid breadth (otion-otion); 24, maximal breadth of occipital condyles; 25, nasal aperture height; 26 , nasal aperture breadth; 27 , height of foramen magnum (basionopisthion); $\mathbf{2 8}$, breadth of foramen magnum; $\mathbf{2 9}$, bullae ossae length; $\mathbf{3 0}$, bullae ossae breadth; 31, cranial height (acrocranion-basion); and 32, maximal cranial height (staphylion-frontal).
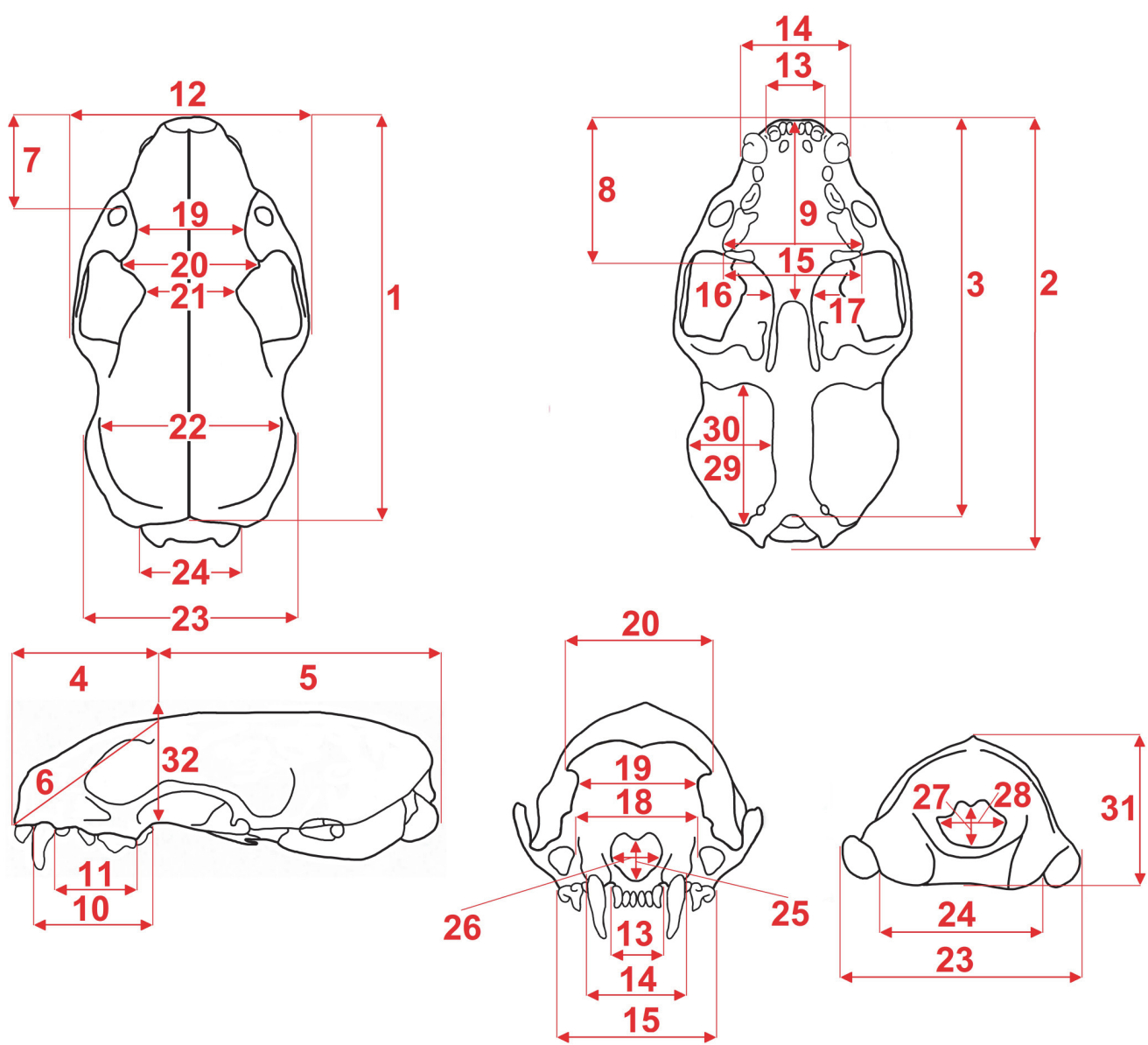


\section{APPENDIX 4.}

Measurements of the mustelid mandible. 1, total length (condyle to infradentale); 2 , angular process to infradentale length; $\mathbf{3}$, infradentale to anterior margin of masseter fossa; $\mathbf{4}$, anterior margin of $\mathrm{c} 1$ to posterior margin of $\mathrm{m} 2 ; \mathbf{5}$, cheek teeth row length (anterior margin of $\mathrm{p} 2$ to posterior margin of $\mathrm{m} 2$ ); $\mathbf{6}$, premolars row length (anterior margin of $\mathrm{p} 2$ to posterior margin of $\mathrm{p} 4$ ); $\mathbf{7}$, molars row length (anterior margin of $\mathrm{m} 1$ to posterior margin of $\mathrm{m} 2$ ); $\mathbf{8}$, distance between mental foramens; $\mathbf{9}$, posterior margin of $\mathrm{m} 2$ to condyle length; $\mathbf{1 0}$, angular process to coronoid process height; 11, mandible maximal height; 12 , body mandible height between p3 and p4; 13 , body mandible thickness between $\mathrm{p} 3$ and $\mathrm{p} 4 ; 14$, body mandible height between $\mathrm{m} 1$ and $\mathrm{m} 2 ; 15$, body mandible thickness between $\mathrm{m} 1$ and $\mathrm{m} 2$; 16, condyle height; 17, condyle breadth; 18, symphysis maximal diameter; and 19 , symphysis minimum diameter.
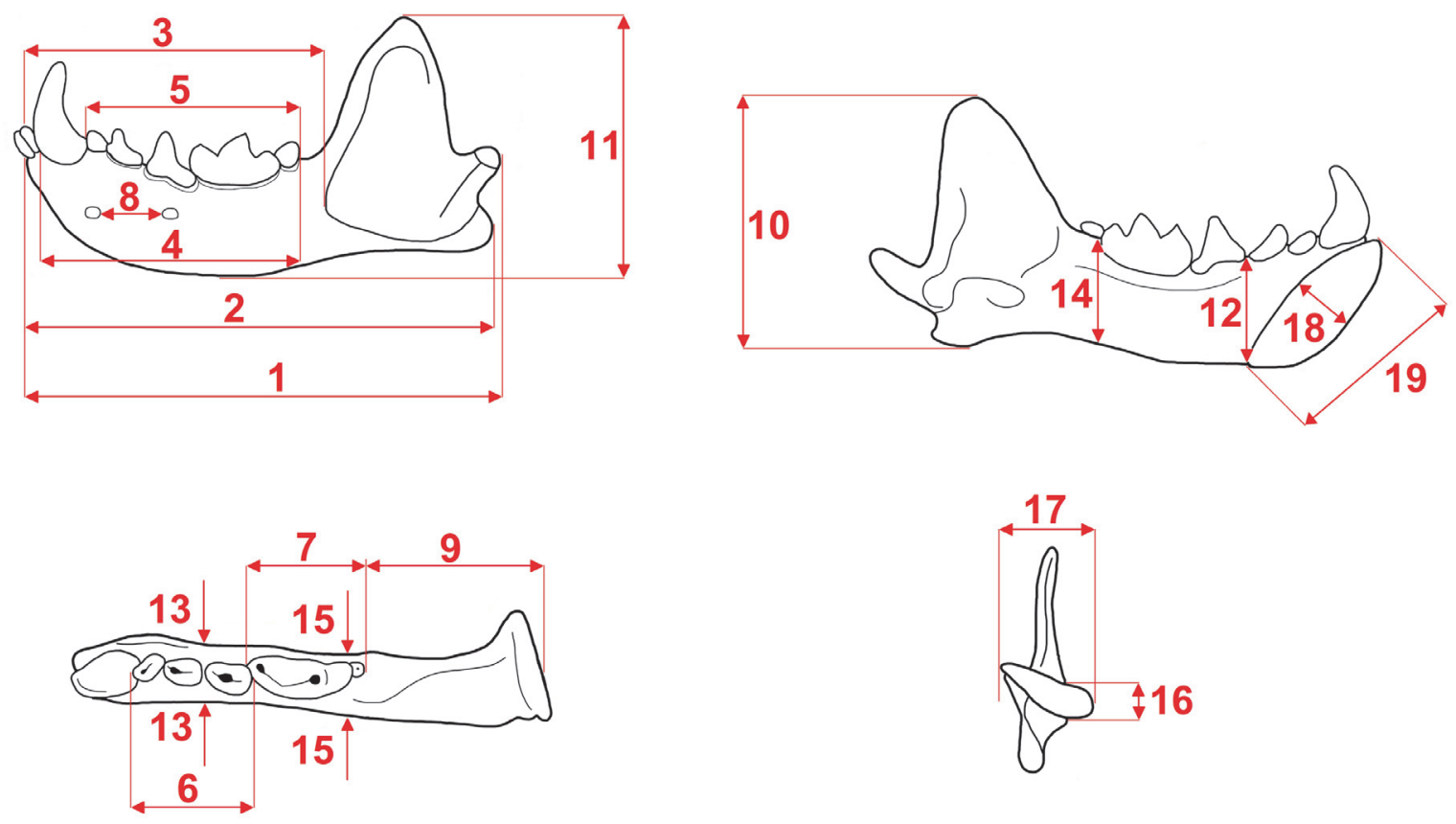


\section{APPENDIX 5.}

Measurements (left) and cusp terminology (right) of the felid lower carnassial (m1). Abbreviatios: $L$, total length; $L$ tri, trigonid length; $L$ tal, talonid length; $B$ tri, trigonid breadth; $B$ tal, talonid breadth; tri, trigonid; tal, talonid; par, paraconid; pro, protoconid; met, metaconid; and hyp, hypoconid.
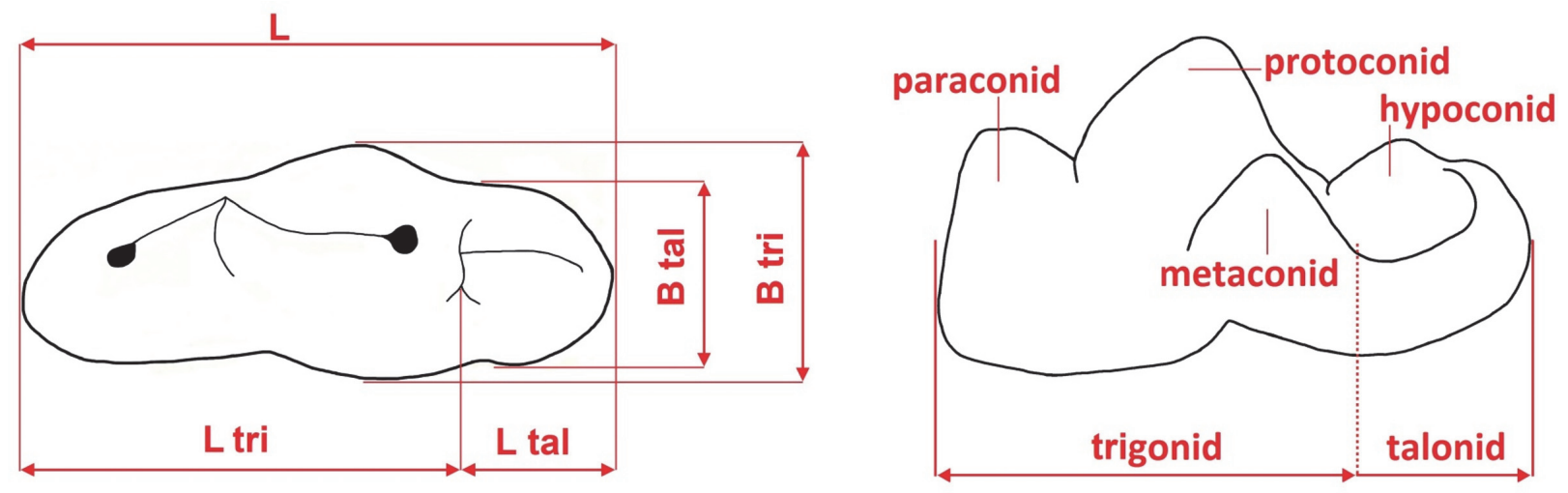


\section{APPENDIX 6.}

Measurements of the felid mandible. 1, total length (infradentale to condyle); 2, length of infradentale to angular process; 3 , infradentale to coronoid process length; 4 , infradentale to anterior margin of masseter fossa; $\mathbf{5}$, anterior margin of $\mathrm{c} 1$ to posterior margin of $\mathrm{m} 1 ; \mathbf{6}$, posterior margin of $\mathrm{c} 1$ to posterior margin of $\mathrm{m} 1 ; \mathbf{7}$, diastema length; $\mathbf{8}$, length of cheek tooth row (anterior margin of $\mathrm{p} 3$ to posterior margin of $\mathrm{m} 1$ ); $\mathbf{9}$, length of premolar row (anterior margin of $\mathrm{p} 3$ to posterior margin of p4); 10, distance between mental foramina; 11, angular process to coronoid process height; 12, symphysis maximum diameter; 13, symphysis minimum diameter; 14, condyle height; 15, condyle breadth; 16, mandible body height before $\mathrm{p} 3 ; \mathbf{1 7}$, mandible body thickness before p3; 18, mandible body height behind $\mathrm{m} 1$; and 19, mandible body thickness behind $\mathrm{m} 1$.
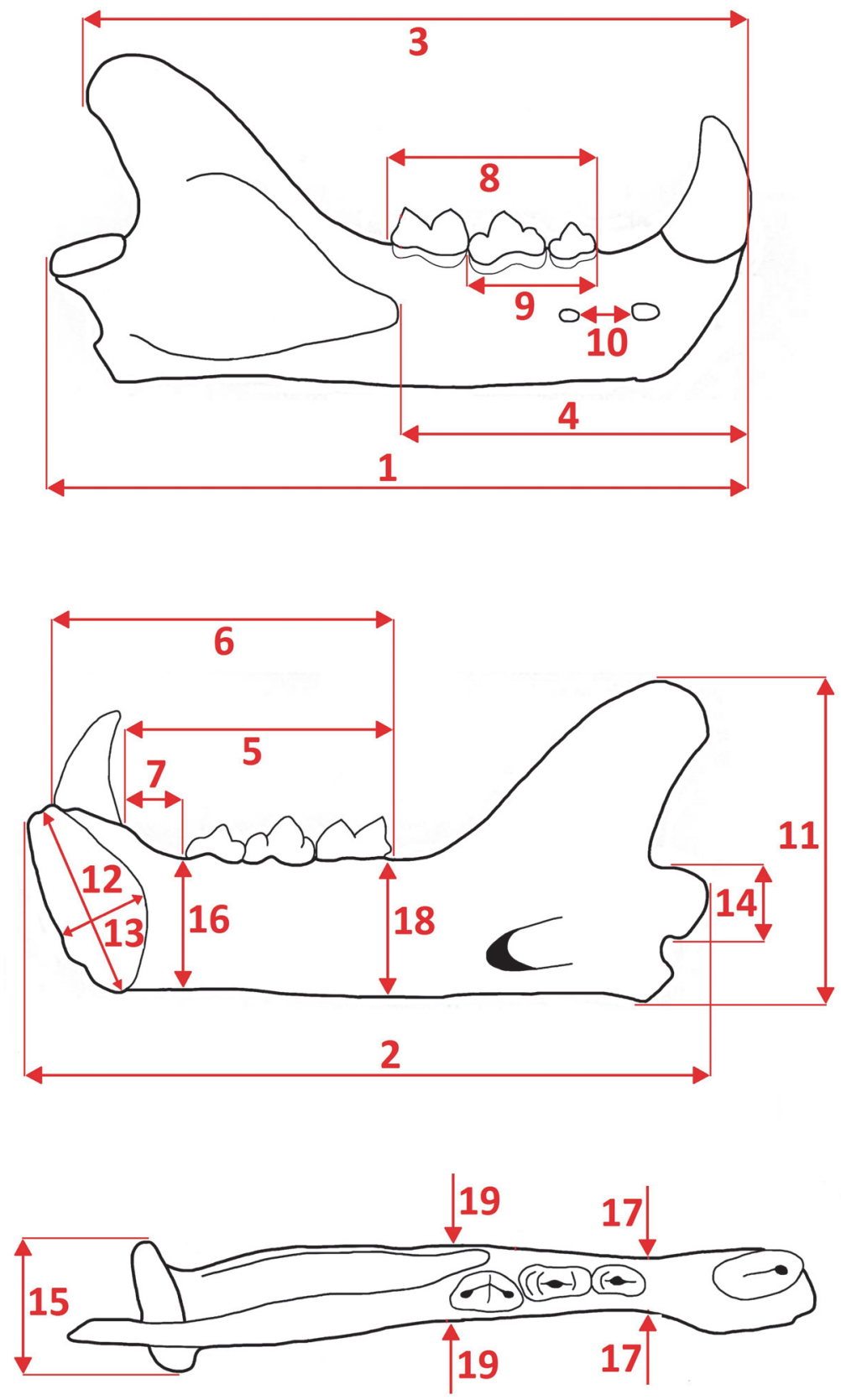


\section{APPENDIX 7.}

Measurements of the felid $\mathrm{p} 3 / \mathrm{p} 4$ and $\mathrm{m} 1$ (modified from Schmid, 1940). Left: lateral view; right: occlusal view. Measurements of premolar: 1, total length; 2 , protoconid length; 3, protoconid height; $\mathbf{4}$, anterior breadth; and $\mathbf{5}$, posterior breadth. Measurements of $\mathrm{m} 1$ : $\mathbf{1}$, total length; $\mathbf{2}$, paraconid length; 3, paraconid height; 4, protoconid length; 5, protoconid height; 6, incisor height; and 7, breadth. Abbreviations: Pa, paraconid; Pr, protoconid; H, hypoconid; T, talonid; C, cingulum; mes, mesial side; dist, distal side; ling, lingual side; bucc, buccal side.
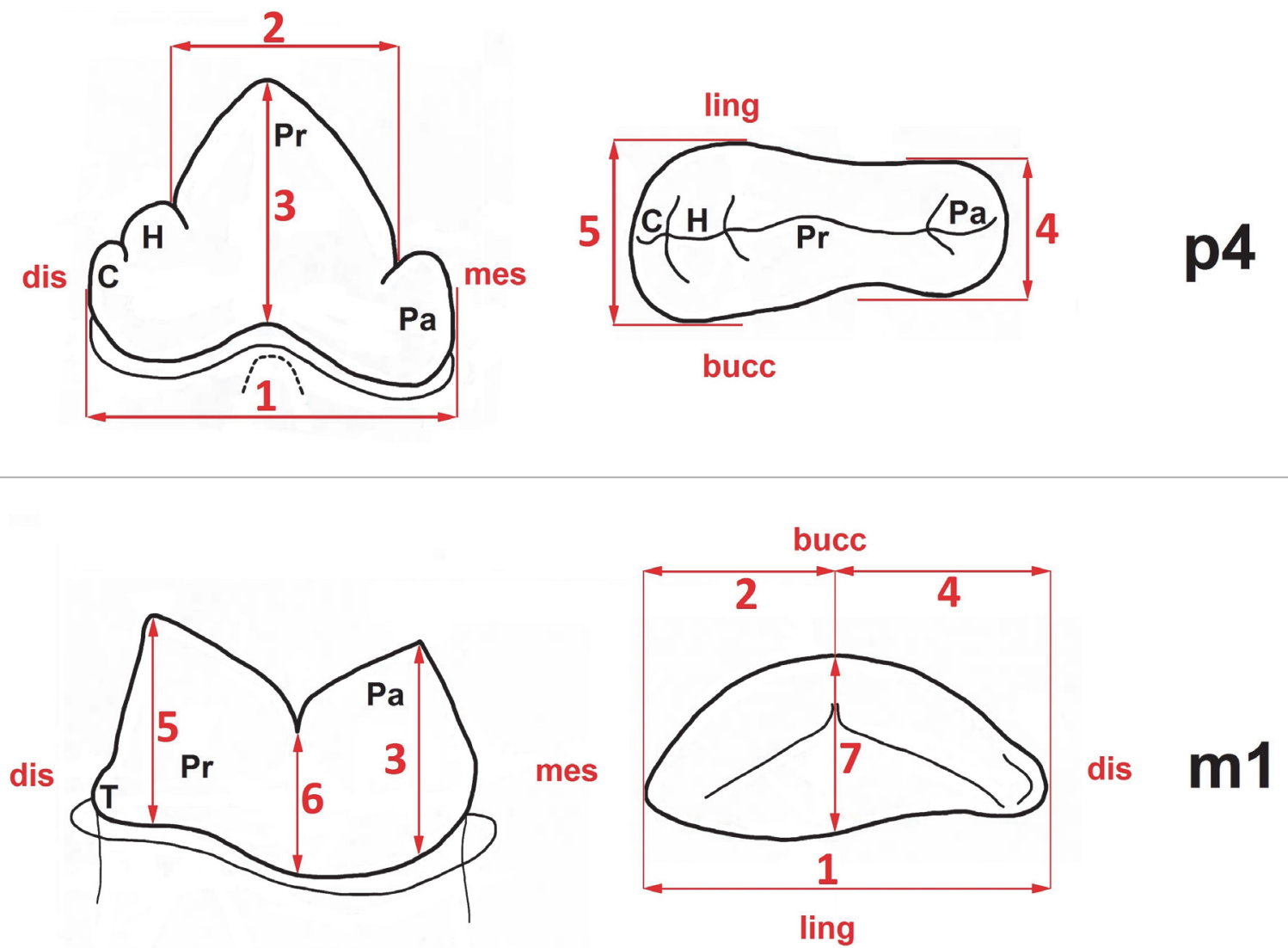


\section{APPENDIX 8.}

Measurements (in mm) of Gulo gulo postcranials from Solna Jama Cave. See Appendices 3 and 4 for measured parts.

\begin{tabular}{|c|c|c|c|c|c|c|c|c|}
\hline Bone part and collection no. & $\mathbf{L}$ & pl & $\mathrm{pB}$ & $\mathrm{mL}$ & $\mathrm{mB}$ & $\mathbf{d L}$ & $\mathrm{dB}$ & B \\
\hline Humerus (JSJ/Gg/1-5) & & & & 15.85 & 14.79 & & & \\
\hline Radius (JSJ/Gg/1-6) & 134.86 & 18.93 & 12.56 & 11.44 & 8.91 & 26.71 & 17.23 & \\
\hline Mtcp I (JSJ/Gg/1-27) & 36.42 & 9.72 & 9.82 & 4.71 & 5.57 & 7.58 & 8.32 & \\
\hline Mtcp I (JSJ/Gg/1-28) & 47.15 & 10.33 & 8.49 & 5.46 & 6.83 & & 10.56 & \\
\hline Mtcp III (JSJ/Gg/1-29) & 55.38 & 11.98 & 9.91 & 5.71 & 7.16 & 9.72 & 10.94 & \\
\hline Mtcp IV (JSJ/Gg/1-30) & & 12.49 & 9.19 & 5.76 & 7.31 & & & \\
\hline Mtcp V (JSJ/Gg/1-31) & 46.98 & 10.08 & 10.96 & 5.39 & 7.06 & 8.84 & 9.34 & \\
\hline Mtts I (JSJ/Gg/1-32) & & & & 5.36 & 6.54 & 7.80 & 8.78 & \\
\hline Mtts II (JSJ/Gg/1-33) & 57.36 & 11.16 & 8.17 & 5.82 & 7.56 & 9.26 & 10.64 & \\
\hline Mtts III (JSJ/Gg/1-34) & 64.65 & 14.76 & 11.24 & 6.67 & 8.14 & 9.42 & 11.32 & \\
\hline Mtts IV (JSJ/Gg/1-35) & 68.69 & 14.98 & 10.21 & 6.84 & 7.93 & 9.54 & 11.23 & \\
\hline Mtts V (JSJ/Gg/1-36) & 63.47 & 10.66 & 12.08 & 6.71 & 7.39 & 9.71 & 11.20 & \\
\hline Calcaneus (JSJ/Gg/1-18) & 54.27 & & & & & & & 28.86 \\
\hline Talus (JSJ/Gg/1-19) & 36.14 & & & & & & & 27.06 \\
\hline Left pisiform (JSJ/Gg/1-20) & 21.50 & 11.75 & 12.58 & & & & & \\
\hline Right pisiform (JSJ/Gg/1-21) & 21.68 & 11.69 & 12.92 & & & & & \\
\hline Navicular (JSJ/Gg/1-22) & 19.97 & & & & & & & 15.47 \\
\hline Cuboid (JSJ/Gg/1-23) & 15.46 & & & & & & & 15.11 \\
\hline Cuneiform I (JSJ/Gg/1-24) & 13.67 & & & & & & & 7.59 \\
\hline Cuneiform II (JSJ/Gg/1-25) & 9.74 & & & & & & & 6.65 \\
\hline Cuneiform III (JSJ/Gg/1-26) & 16.81 & & & & & & & 9.85 \\
\hline Phalange I (JSJ/Gg/1-37) & 28.84 & 8.52 & 10.87 & 5.68 & 6.18 & 5.63 & 8.58 & \\
\hline Phalange I (JSJ/Gg/1-38) & 29.60 & 7.94 & 11.22 & 6.19 & 6.56 & 6.13 & 8.80 & \\
\hline Phalange I (JSJ/Gg/1-39) & 29.90 & 8.16 & 10.52 & 5.15 & 6.23 & 6.05 & 8.02 & \\
\hline Phalange I (JSJ/Gg/1-40) & 29.97 & 8.57 & 10.81 & 4.97 & 6.31 & 5.90 & 8.49 & \\
\hline Phalange I (JSJ/Gg/1-41) & 26.39 & 8.32 & 10.99 & 5.36 & 6.52 & 5.89 & 8.59 & \\
\hline Phalange I (JSJ/Gg/1-42) & 26.54 & 8.74 & 11.04 & 5.33 & 6.69 & 6.68 & 8.36 & \\
\hline Phalange I (JSJ/Gg/1-43) & 25.12 & 6.45 & 9.50 & 4.25 & 6.32 & 6.27 & 7.63 & \\
\hline Phalange I (JSJ/Gg/1-44) & 24.68 & 7.82 & 9.67 & 4.61 & 5.51 & 5.82 & 7.43 & \\
\hline Phalange I (JSJ/Gg/1-45) & 30.02 & 9.02 & 11.18 & 5.27 & 6.94 & 6.12 & 8.85 & \\
\hline Phalange I (JSJ/Gg/1-46) & 29.39 & 8.65 & 10.97 & 5.21 & 6.44 & 6.69 & 8.62 & \\
\hline Phalange I (JSJ/Gg/1-47) & 25.61 & 8.05 & 10.80 & 5.25 & 6.66 & 5.89 & 7.96 & \\
\hline Phalange I (JSJ/Gg/1-48) & 26.25 & 8.34 & 10.72 & 4.98 & 6.69 & 5.80 & 7.66 & \\
\hline Phalange I (JSJ/Gg/1-49) & 27.06 & 8.62 & 10.47 & 5.24 & 6.58 & 6.01 & 8.23 & \\
\hline Phalange I (JSJ/Gg/1-50) & 24.42 & 7.14 & 9.29 & 4.80 & 5.95 & 5.86 & 7.11 & \\
\hline Phalange II (JSJ/Gg/1-51) & 17.63 & 8.11 & 8.76 & 4.36 & 5.16 & 6.76 & 6.69 & \\
\hline Phalange II (JSJ/Gg/1-52) & 23.55 & 7.87 & 9.39 & 4.64 & 5.21 & 7.03 & 7.96 & \\
\hline Phalange II (JSJ/Gg/1-53) & 17.71 & 7.51 & 9.01 & 4.71 & 5.61 & 6.42 & 7.49 & \\
\hline Phalange II (JSJ/Gg/1-54) & 18.94 & 7.21 & 8.85 & 4.43 & 5.62 & 6.63 & 7.76 & \\
\hline Phalange II (JSJ/Gg/1-55) & 22.25 & 7.49 & 9.35 & 4.64 & 5.48 & 6.63 & 7.87 & \\
\hline Phalange II (JSJ/Gg/1-56) & 21.85 & 6.41 & & & & 6.31 & & \\
\hline Phalange II (JSJ/Gg/1-57) & 20.74 & 7.17 & 8.63 & 4.44 & 5.34 & 7.22 & 7.79 & \\
\hline
\end{tabular}


Appendix 8 (continued).

\begin{tabular}{l|cccccccc}
\hline Bone part and collection no. & $\mathbf{L}$ & $\mathbf{p l}$ & $\mathbf{p B}$ & $\mathbf{m L}$ & $\mathbf{m B}$ & $\mathbf{d L}$ & $\mathbf{d B}$ & $\mathbf{B}$ \\
\hline Phalange II (JSJ/Gg/1-58) & 22.38 & 7.42 & 9.32 & 4.69 & 5.38 & 7.09 & 7.81 & 7.67 \\
Phalange II (JSJ/Gg/1-59) & 22.13 & 7.13 & 9.09 & 4.39 & 6.08 & 6.98 & 7.71 \\
Phalange II (JSJ/Gg/1-60) & 21.97 & 7.27 & 9.13 & 4.48 & 5.26 & 6.72 & 7 \\
\hline
\end{tabular}

